\title{
THE USE AND LIMITATIONS OF FILTER-PAPER ELECTROPHORESIS
}

\author{
BY \\ N. H. MARTIN AND G. T. FRANGLEN \\ From the Department of Chemical Pathology, St. George's Hospital, London
}

(RECEIVED FOR PUBLICATION APRIL 2, 1954)

In 1935 Tiselius, using the apparatus he had devised in 1930, demonstrated that human serum globulin fell into three reasonably defined groups based on their electrophoretic mobilities. For the next 15 years a steady flood of papers reported the fluctuations of albumin and the globulins in young and old, in health and disease, as disclosed by analyses carried out using Tiselius apparatus with and without the numerous minor modifications which were introduced.

In spite of brilliant efforts at simplification it was evident that the method, because of its relative complexity, could never have widespread use in routine clinical chemistry. In 1950 three groups of workers, among them Tiselius himself, described methods which indicated that, using filter paper as a matrix, a relatively cheap and rapid method could be evolved of obtaining a rough analysis of the serum proteins akin to the analysis obtained by the classical technique.

The method required no more than $0.5 \mathrm{ml}$. of serum, and though estimates of the total protein concentration would still have to be made by other means, it was conceivable that this simple technique would dispense with the tedious salt fractionation and subsequent analyses required heretofore to obtain the albumin/globulin ratio.

The last four years have produced a spate of papers devoted to the description of modifications in methods of separation and analysis with numerous technical and mathematical tricks for improving the correlation of the results with the substantial body of data already obtained with the classical technique. With few notable exceptions scant attention was paid to the fundamental principles underlying the technique or to the points in which their application to it differed from the classical procedure.

As paper succeeded paper it became increasingly evident that except within fairly wide limits the two methods were not quantitatively comparable. Even worse, because of lack of time spent on a consideration of the basic principles involved, it seemed probable that differing techniques for the production of "electrophoretograms" were not comparable among themselves.

One was faced with the prospect of scores of laboratories turning out hundreds of results year by year ; each group, because of deviations in technique unappreciated and therefore unrecorded, differing to an unknown extent one from the other. The clinical chemical chaos that could arise demanded a reassessment of the situation in the hope that workers in the field would stop, think, and start again.

Electrokinetic phenomena, as the derivation of the word implies, are concerned with the production of electrical manifestations by the movements of particles in liquids and conversely the production of orientated movement of particles in a liquid medium when an electrical current is passed through it.

In 1809 , barely 10 years after Volta had built the first galvanic cell, Reuss, a Russian physicist, stuck two vertical glass tubes into a piece of wet clay, filled each with water and then carefully placed a layer of fine sand in the bottom of each tube. The terminals from the battery which he had fashioned, out of 74 roubles and 74 zinc pieces, were led into the tubes. When the switch on his circuit was closed he observed that the clear water at the positive pole became milky from the migration of fine particles. Moreover, he noted that though the water at the negative pole remained clear its volume increased. This experiment is the first clearly recorded observation of two electrokinetic effects, electrophoresis, the migration of the clay particles through the water, and electro-osmosis (endosmosis), the migration of water through the porous plug of clay.

The other two electrokinetic effects which may be represented as the converse of these two observations are the production of an electrical potential by the flow of a liquid through a tube, and the production of an electrical potential by 
the movement of particles sedimenting in a liquid column. The first of these was described and investigated by Quinke in 1859 and 1861. It is commonly referred to as streaming potential. The second was examined by Dorn in 1880 and is referred to as sedimentation potential or the Dorn effect.

All these four phenomena are usually attended by certain secondary effects due to the inevitable modifications of the existing properties of the system in which they take place. Perhaps the most important is the electroviscous effect which is the demonstrable increase in viscosity of the solution during the application or production of the electrical potential. In addition the dissipation of heat produced during the passage of an electrical current may materially alter the spatial relation of particles migrating under the current's influence by the creation of secondary convections.

The development of electrokinetic theory has shown that the four principal phenomena have much in common and that the laws which hold for one apply with only minor modification to all. It is evident too that in practice it is very difficult to create an apparatus for the demonstration of the electrophoretic effect that will not also involve the consideration of one of the other effects, streaming potential or electro-osmosis.

It is important to realize that though clay and water were the materials with which Reuss made his initial experiments, had he used soda water or champagne he might have observed the ordered migration of the bubbles of gas just as he did the particles of clay. Moreover, suspensions of oil droplets in water will migrate with equal facility to the positive pole though they are not normally regarded as existing in an ionized form in the sense that the sodium ion or chlorine ion would be. It would appear then that these particles have in some way acquired a charge and it was in attempts to explain how and why they could acquire a charge that the concept of the electrical double layer developed. The modern concept is that the differences in behaviour of the large and small molecules are ones of degree, and are all finally related to the distribution of electron densities in the system.

\section{The Tiselius Apparatus}

Three techniques have been developed in research laboratories for the measurement of electrophoretic movement. Of these, "the moving boundary technique," in which the movement of the boundary is measured between a solution of the molecule being investigated and the solvent, had fallen into disrepute because of the technical difficulty of forming, maintaining, and observing the boundary with sufficient accuracy.

In 1930 Tiselius published his thesis. In the next seven years, so great were the improvements in the technique initiated by him $(1937,1938)$ that from being the Cinderella among the methods for $\mathbb{Q}$ measuring the electrophoretic effect the moving क boundary technique became one of the most popular. It was not only that these improvements enabled new light to be thrown on old problems but $\overrightarrow{\vec{\omega}}$ that it now became possible to analyse mixtures of soluble proteins and to characterize them without materially modifying their intrinsic structure. This $-v$ was revolutionary, and it is proper therefore to i recapitulate the improvements which Tiselius initiated.

The Construction of the $U$ Tube.-Burton in 1906 had used a simple $U$ tube for the study of boundary migration. Over the next 20 years $\vec{\oplus}$ various modifications had been made to it. But $\stackrel{\oplus}{\oplus}$ Tiselius altered its shape from a cylindrical to an oblong cross-section, so that not only could accurate observations be made on the deflection of parallel beams of light of any wavelength passing through the tube and the liquid it contained, but convections due to uneven heat dissipation through the liquid in the tube were greatly reduced.

The Formation of the Boundaries.-Tiselius introduced a shearing technique and obtained by it much clearer and more consistent starting boundaries than had previously been obtained by the old methods of displacement. This he did by breaking his tube into four sections: the top section, which was simply the connecting link between the $U$ tube proper and the electrode vessels ; the upper and lower middle sections, which formed the limbs of the $U$ and through which the analytical measurements were made, and the base section which contained the linking channel between the two limbs (Figs. 1 and 2). The boundaries were made by sliding the lower of the middle sections across between the upper and the base sections after complete temperature equilibration.

The Elimination of Density Gradients.-As Tiselius was largely concerned with observations in aqueous solution, he appreciated and arranged that the solution being examined, being more dense than the buffer against which it had been dialysed, should be placed in the bottom sections of his $U$ tube, and that equilibration and migration should be carried out at or near $4^{\circ} \mathrm{C}$., the maximum density of water. 
The Observation of Colourless Boundaries.-To observe the movement of the colourless boundaries with which he was largely concerned, he borrowed from the physicists the delicate TöplerSchlierin method for observing minute changes

A

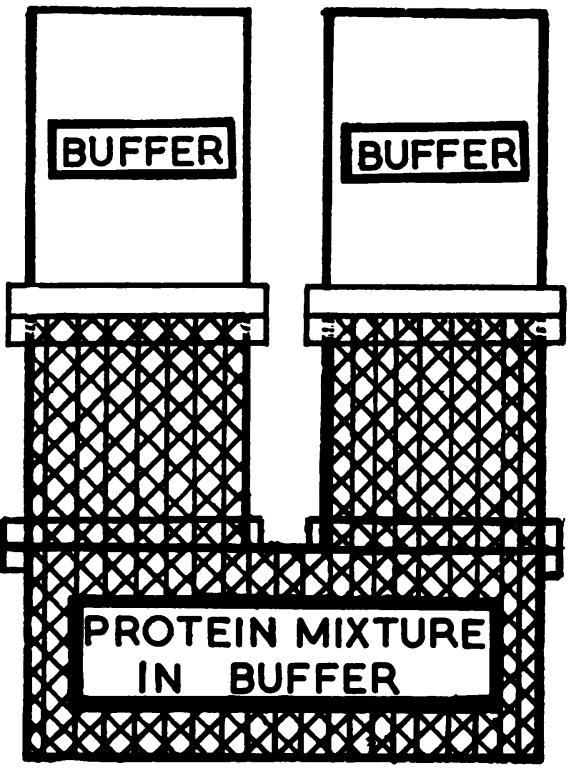

B

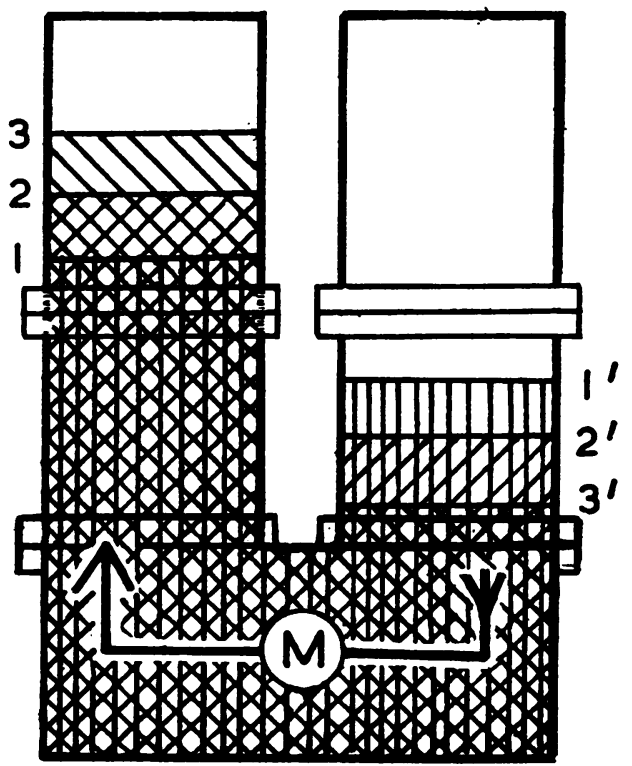

FIG. 1.-Diagramatic representation of the Tiselius " $U$ " tube. A shows the starting boundaries. B shows the position of the boundaries after passage of the current. $M$ shows the direction of the current. 321 show the moving boundaries on the " ascending side." " $3{ }^{\prime}, 2^{\prime} 1^{\prime}$ show the moving boundaries on the " descending side." in refraction. This method had been used for many years to test lenses for chromatic and spherical aberration. It depends on the fact that, if parallel light beams are brought to a point of focus by the lens under test and a screen placed at the focal point of the lens so that it just covers the image of the light source produced there, the field seen in a telescope placed beyond the screen and focused on the lens will appear dark provided there are no defects in the lens which have deflected the beams of light. If there are any such defects these will appear luminous in the otherwise dark field.

Töpler (1867) realized that the "defect" could be a small variation in refractive index in a column of liquid placed immediately in front of a perfect lens and used the technique for measuring minute variations of refractive index in liquids. It is from his modification of the original technique that modern Schlierin scanning techniques have all been developed.

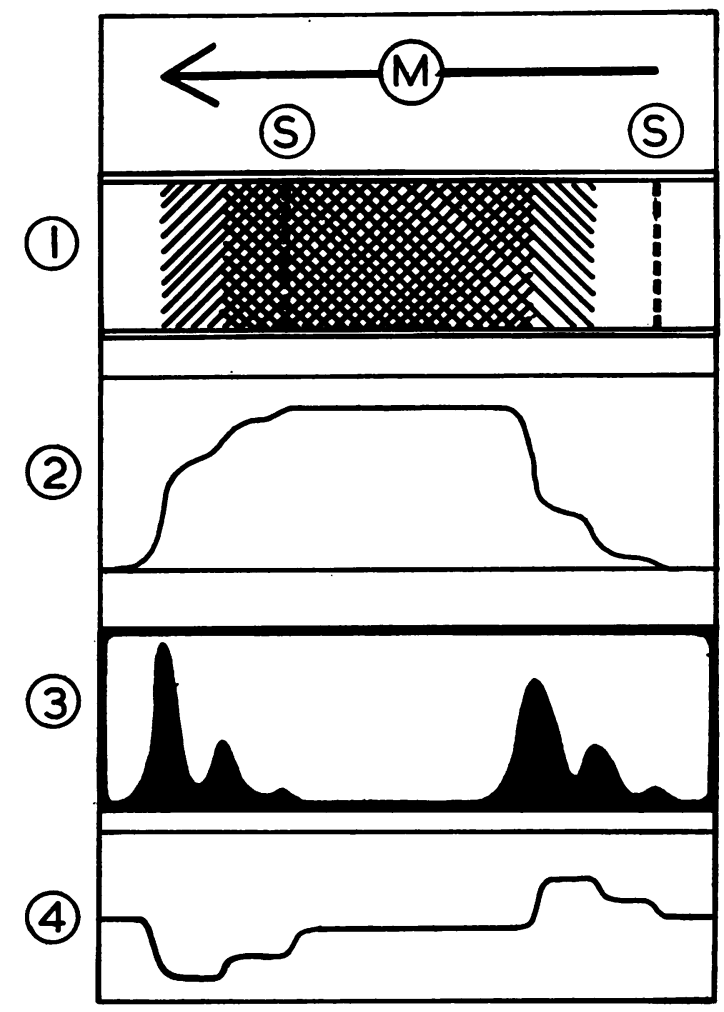

FIG. 2.-1 is a schematic representation of two proteins migrating in the classical apparatus (the $U$ tube has been straightened) $\mathbf{M}=$ Direction of migration. $\mathbf{S}=$ Salt protein boundaries. 2 is a tracing of changes of the refractive index over the area of migration, 3 is the Schlierin pattern-the rate of change of the refractive index variation of conductivity through the area of migration illusvariation of conductivity through the area
trating the change across the salt boundary. 
Over the last 15 years numerous modifications in detail have been introduced. Not all are improvements. In 1938 Philpot introduced a cylindrical lens into the optical system for Schlierin scanning which made it possible to watch the progress of separation of the components during an electrophoretic analysis. Longsworth (1942) described the single centre section which enables detailed analysis of mixtures to be made over the whole length of each limb.

Svensson (1946) described improved compensators by which the rate of forward migration of a protein could be controlled, and Hoch (1950) gave mathematical foundations to the considerations of "the steady state" by which the "purity" of a sample of a protein might be determined. Numerous modifications to electrode vessels and to the method of their junction with the $U$ tube have been described (Svensson, 1946; Alberty, 1948). The $U$ tube itself has been constructed successfully out of perspex instead of glass and the whole apparatus condensed in form (Longsworth and Alberty, demonstrated by Crook, El-Marsafy, Shooter, and Ward, 1952). The use of perspex may well materially reduce the cost of the apparatus, but the physical characteristics of perspex make it necessary either to reduce the temperature of the thermostatic bath or to lower the current densities at which analyses are carried out.

Finally a number of workers have described compact forms of apparatus using smaller amounts of material, having simplified thermostatic control, and modified cells (Moore and White, 1948 ; Stern and Reiner, 1946 ; Antweiler, 1947, 1949 ; Alexander and Saggers, 1948 ; Svensson, 1950) for routine analytical use. We believe that the majority of these micro modifications lose something of the original quality of the apparatus as ultimately developed by Tiselius (1937) and by Longsworth (1942).

\section{Electrophoresis on Paper}

The classical technique, as carried out in the apparatus designed by Tiselius or in the many modifications based on the original apparatus, is unlikely, by reason of its complexity, to be used widely in routine clinical laboratories in this country.

For this reason the relatively simple technique of paper electrophoresis requires special consideration. In comparing the two techniques it is always important to remember that, whereas in the classical technique one is measuring a series of zones of concentration superimposed successively one on the other, in the paper and allied techniques there is relatively complete separation of the individual components.

The Apparatus.-Numerous papers have been written on the design and construction of paper electrophoresis apparatus. The complexity of these designs varies enormously, ranging from the use of glass tumblers to elaborate constructions of "perspex." Nevertheless three distinct classes can be recognized: (a) those in which the paper is supported in the centre to form an inverted $\mathrm{V}$; (b) those in which the paper or other medium is horizontal; and (c) those in which the paper or medium is hung or packed vertically.

Each of these classes has certain characteristics. ?

The Inverted $V$ Type (Durrum, 1950; Flynn 0 and de Mayo, 1951; Latner, 1952). -This type (Fig. 3) has been used widely in hospitals in $\vec{z}$ Britain to separate serum and plasma proteins. One of its advantages over other types is that a technique can be acquired quickly which gives $\mathcal{O}$

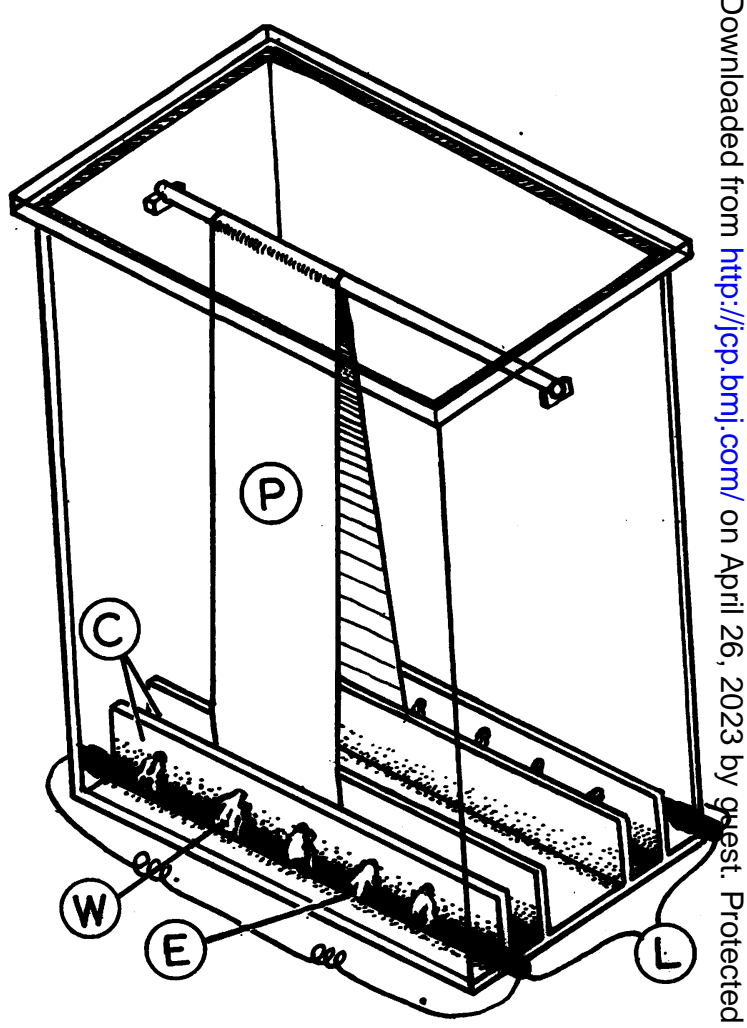

FIG. 3.-Diagram of the inverted " $V$ " type of apparatus after Flynn and de Mayo. $\mathrm{C}=$ buffer chambers, $\mathrm{E}=$ electrodes,
$\mathrm{L}=$ leads to electrodes, $\mathrm{W}=$ " wicks " between buffer chambers: $O$ $\mathbf{P}=$ paper. 
results sufficiently good for rough clinical analyses. It is unsuitable for the study of fundamental problems concerning electrophoresis, as conditions are too complex to control. In none of the apparatus of this type examined by the authors does the enclosed atmosphere reach a uniform temperature or vapour saturation. This is due partly to the limited surface of evaporation available to saturation of the relatively large air space, and partly to the temperature differences from the heating effect of the electric current. As a result, buffer continuously ascends the paper strip during a run, and is concentrated by the distillation of water vapour from the strip. Moreover, the arrangement of the strip results in the volume of liquid absorbed by unit quantity of paper being proportional to the height of that unit above the buffer level. The conditions therefore under which electrophoresis takes place are as follows: in addition to the electro-osmotic flow of buffer, there is also a "distillation" flow from the ends of the strip to the centre. At the same time there is an increase in the ionic strength of the buffer from the ends of the strip to the centre, a decrease in the volume of buffer held by the strip. It should be noted that such changes of ionic strength generally result in an alteration of the buffer $p \mathrm{H}$. When buffers containing volatile constituents such as acetic acid are used, the conditions are complicated by the preferential loss of these constituents through increased evaporation as the centre is approached. This leads to a marked change in the $p \mathrm{H}$ of the buffer. Under these conditions it is impossible to attain a constant potential gradient along the strip, and it is not surprising that Durrum (1950) reported that a uniform rate of movement of albumin was not attained in his apparatus, a result we have been able to confirm. In another paper Durrum (1951c) reports that in prolonged electrophoresis amino-acids take up equilibrium positions which are unaffected by their original positions on the papers, and he explains this by consideration of the opposing effects on ionic migration of the buffer flow along the paper, and of the gradients in ionic strength of the buffer. The theoretical aspect of this system has been studied in detail by Macheboeuf (1953).

This type of apparatus has been adapted to twodimensional separation, and by this means Durrum (1951c) has separated 11 out of a mixture of 19 amino acids, using acid and alkaline solvents. He also found that it was possible to obtain reproducible patterns from serum proteins by two- dimensional electrophoresis, but changes due to denaturation were liable to complicate the result.

The Horizontal Type.-This type (Fig. 4) has been developed from the original design of Cremer and Tiselius (1950). Several different versions have been described. The paper may be sealed from the air by being sandwiched between two glass plates so that evaporation from the paper strip is completely prevented (Cremer and Tiselius, 1950 ; Kunkel and Tiselius, 1951). In an effort to control the temperature of the strip more accurately Cremer and Tiselius immersed their sandwich in chlorobenzene. Recently Consden and Stanier described a model in which the buffersoaked filter paper was immersed directly into chlorobenzene without glass plates (Consden and Stanier, 1952b). Other means of dissipating heat when running at high potentials have been described (Gross, 1953; Michl, 1952 ; Foster, 1952). In Weber's apparatus the paper rests on a glass plate, but the upper surface is exposed to the atmosphere of the box (Weber, 1951). In several models the paper hangs freely in the horizontal position (Wieland, 1948 ; Grassmann and Hannig, 1952 ; McDonald, Urbin, and Williamson, 1951a ; Franglen, 1953). In all these models the horizontal position of the paper strip eliminates any effect that variation of height may have on the constancy of the buffer uptake. Even in those models in which the paper is not enclosed between glass plates or plunged in organic solvents, the saturation of the relatively small atmosphere is readily achieved. In this laboratory we have developed an apparatus in which the atmosphere about the freely hanging horizontal paper is maintained in a constant condition by the presence of buffer-damped filter paper supported just above and below the working paper (Franglen and Martin, 1954b). Rates of ionic migration are uniform both in the enclosed and the open type of horizontal apparatus, and this has led to attempts to formulate a mathematical theory of paper electrophoresis (Kunkel and Tiselius, 1951; McDonald et al., 1951b). Durrum has pointed out, however, that "when paper is supported on one or both sides, even when the supporting surface is siliconed, a thin film of electrolyte lies at the interface between the paper and the supporting medium in which convection may not be effectively prevented and in which film the mobility may be different from that in the body of the paper" (Durrum, 1951b). This may be a cause of the trailing of protein components which is frequently encountered in techniques in which glass plates are used to confine the paper. Horizontal 


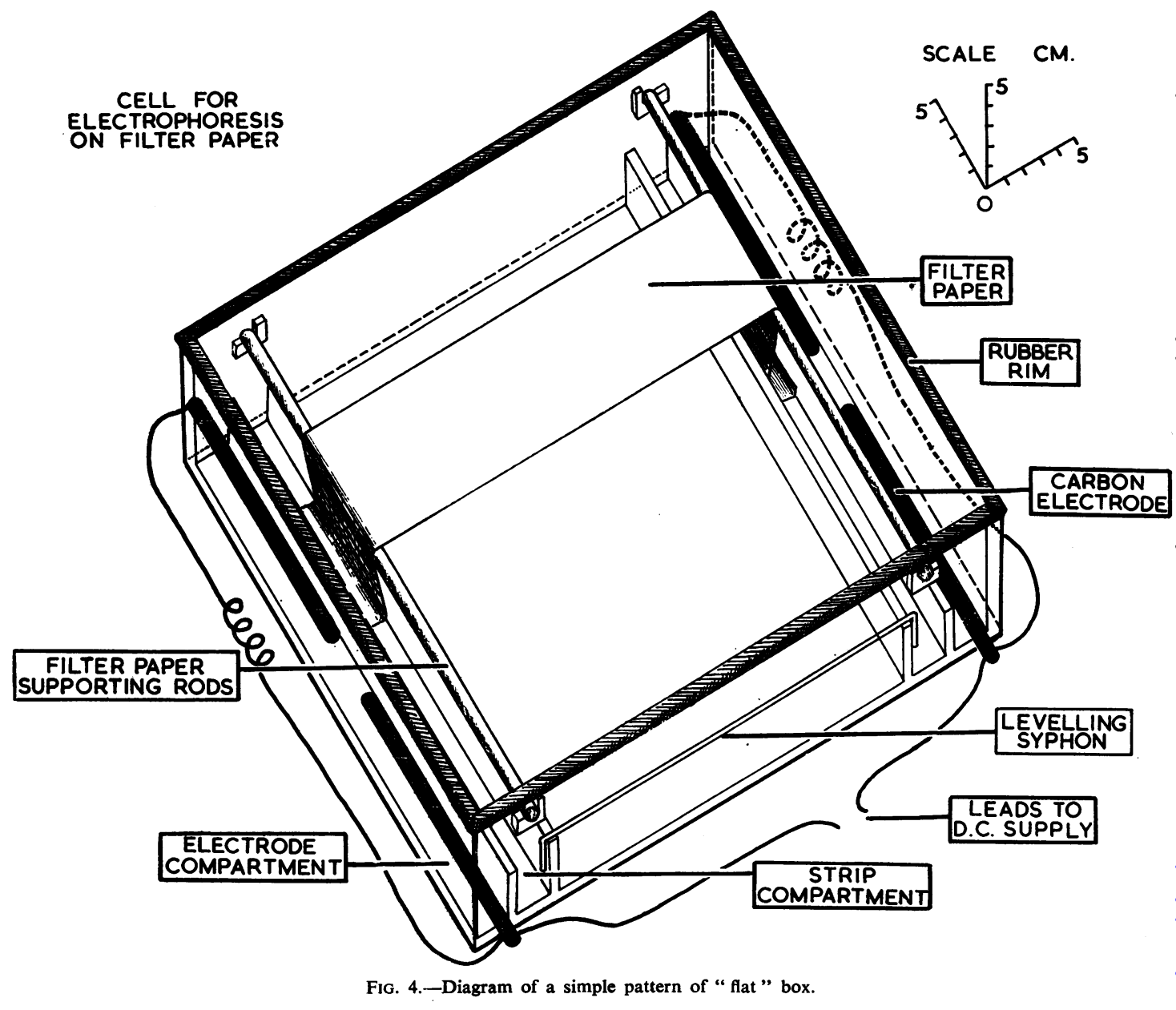

apparatus has been adapted for use with other media such as starch (Kunkel and Slater, 1952a and b) or agar (Gordon, Keil, and Sebesta, 1949).

The Vertical Type.-Although a few models of this type for analytical work have been described, the majority have been designed for the continuous separation of components by zone electrophoresis (Haugaard and Kroner, 1948 ; Svensson and Brattsten, 1950 ; Brattsten and Nilsson, 1950 ; Grassmann and Hannig, 1950 ; Durrum, 1951a).

Preparative Methods Employing Electrophoresis.-The electrophoretic principle seems to present a means of separating proteins without seriously altering their structure.

A number of techniques embodying the principle have been developed. Many consist of modifications of the classical Tiselius apparatus so that zones containing specific migrating components may be removed without seriously disturbing the equilibrium of the remaining migrating boundaries (Maclagan and Bunn, 1947 ; Svensson, 1946 ; Kekwick, Lyttleton, Brewer, and Dreblow, 1951 ; Crook et al., 1952).

These methods, although of great value $N$ to research workers, have little practical use in N routine clinical laboratories. A certain number of methods have been developed in which both electrophoresis and convection have been used together to give a continuous technique for separa- $\stackrel{\infty}{\rightarrow}$ tion, and it is conceivable that the principles might be developed and applied on a commercial scale (Gutfreund, 1943 ; Gralén and Svedberg, 1941 ; Nielsen and Kirkwood, 1946).

Finally, Durrum applied a principle (Durrum, $\cong$ 1951a) originally developed by Svensson and Brattsten to electrophoresis (Svensson and Bratt- \& sten, 1950) on filter paper (Fig. 5). In his and 


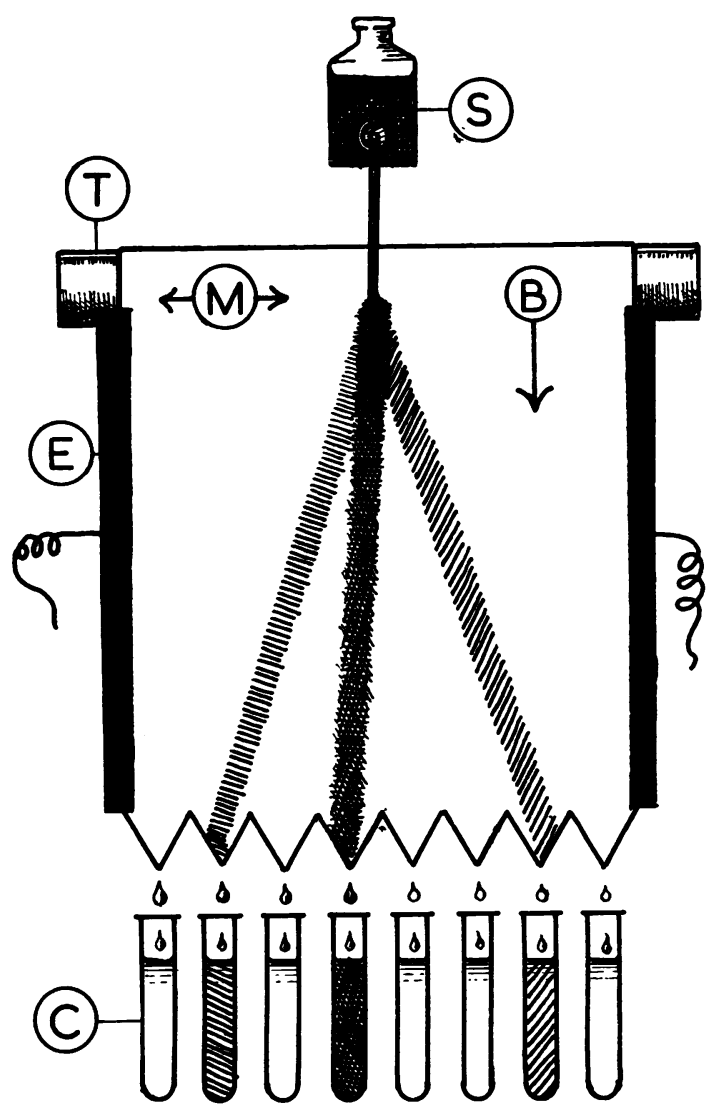

FIG. 5.-Diagram of the preparative method initiated by Durrum using electrophoresis on a vertical sheet of filter paper. $B=$ direction of buffer flow, $\mathrm{C}=$ collecting tubes, $\mathrm{E}=$ electrodes, $\mathbf{M}=$ direction of applied current, $\mathbf{S}=$ reservoir containing solution of proteins for analysis, $T=$ trough containing buffer.

Svensson's method a stream of buffer electrolyte is fed by gravity across a filter paper and at right angles to an electrical current passed through the filter paper.

If a solution of a mixture of proteins is allowed to flow gently from a point on the top edge of the paper it will be washed slowly down with the stream of buffer, moving under the influence of gravity. As the mixture passes down across the paper it will be subjected to the lateral impact of the electrical current moving at right angles to the direction of flow. This current will tend to pull apart the components of the mixture which will have separated, as they would in a simple electrophoretic run, when they reach the lower margin of the filter paper. The lower margin of the paper is serrated and a row of tubes conveniently placed collects the protein-containing buffer solutions as they drip off the paper in a series of fractions.
The original mixture is fed in from the reservoir at the top of the apparatus. The tubes collect the fractionated proteins at the bottom.

While the method may not have very wide application in clinical laboratories it is not very complicated or expensive to construct if at any time there is need for a preparative method.

A preparative model based on a slightly different principle has recently been described by Flodin and Porath (1954).

Necessary Conditions for Separation of Mixtures by Paper Electrophoresis.-Certain conditions for separating the mixtures are necessary and will be discussed.

Control of the Electrical Field : Power Input.If consistent results are to be obtained a constant supply of D.C. with some simple form of voltage control is needed. A 120-volt high-tension dry battery similar to those used in old wireless sets is perfectly satisfactory. In normal daily use they should have a life of about four months and should then be renewed. A simple milliammeter should be included in series in the circuit. With the voltage adjusted to 120 to 150 volts a current density of 0.15 to $0.20 \mathrm{~mA} / \mathrm{cm}$. cross-section of paper should be obtained. Under these conditions in the flat pattern of box using reversible electrodes a satisfactory separation of serum proteins will be obtained on Whatman No. 1 filter paper using 0.05 molar barbiturate buffer at $p \mathrm{H} 8.6$ in 12 to 16 hours.

If a more rapid separation is required, this can be managed by raising the voltage, but at higher voltages there is always a risk of distorting the pattern of the separating serum proteins unless special precautions are taken to prevent heating.

Some laboratories may have a D.C. supply and for those interested the circuit of a simple form of mains transformer incorporating a stabilizer is illustrated here (Fig. 6). This circuit was designed and used in this laboratory by R. G. O. Kekwick and has proved satisfactory.

Electrodes.- "According to the experience of the author reversible electrodes are quite indispensable" (Tiselius's thesis, 1930, p. 14). We agree that if satisfactory voltage control is to be achieved some simple form of non-polarizable electrode must be used in all forms of electrophoretic analysis.

We have found the silver/silver-chloride/ potassium-chloride system, modelled in miniature from that originally designed by Tiselius for the classical apparatus, inexpensive, simple to construct, and reliable in use. Platinum electrodes 


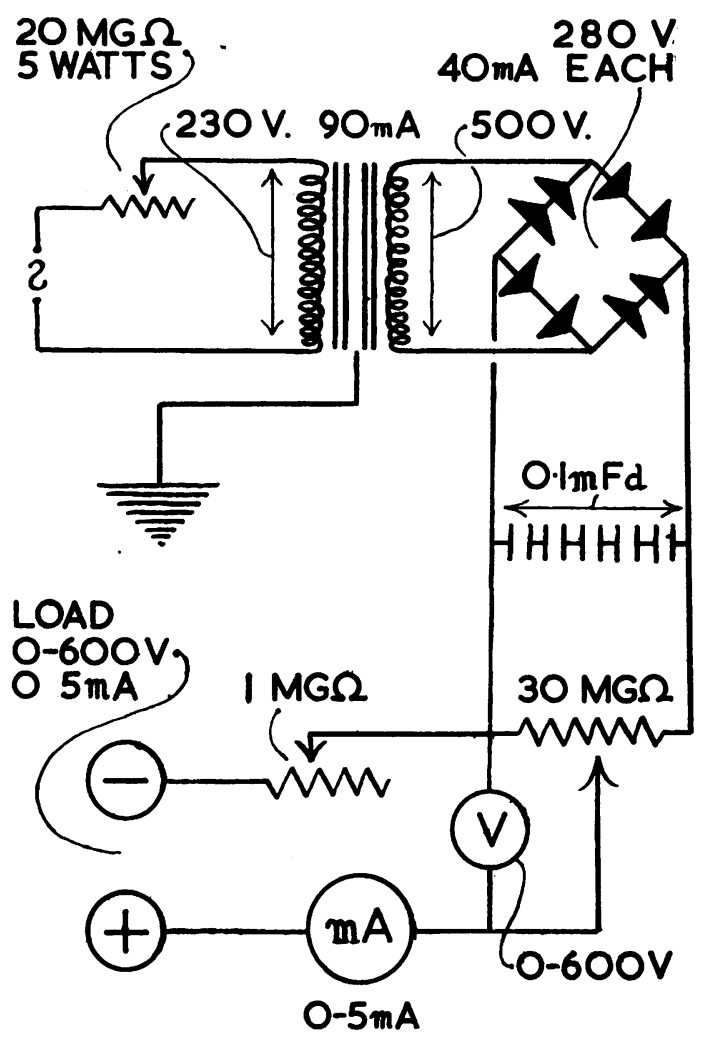

FIG. 6.-Diagram of mains transformer from A.C. to D.C. incorporating a stabilizer.

are equally satisfactory but are relatively expensive. Carbon electrodes are not reversible, polarize rapidly with a resulting tendency to $p \mathrm{H}$ shifts in surrounding buffer, and have a tendency to crumble. They are not satisfactory if any attempt is being made to achieve a steady field strength.

Gardell, Gordon, and Aqvist (1950) have used a platinum anode and a brass cathode.

Preparation of the Material for Electrophoresis. -The protein solution to be analysed should be dialysed against the buffer to be used before electrophoresis. This can be carried out using small cellophane bags, but does inevitably involve using more material than is normally available. In practice the serum to be analysed can be diluted with an equal volume of the buffer provided the final total protein concentration does not fall below 3 g. per $100 \mathrm{ml}$. In many instances satisfactory analysis may be obtained from direct application of the undiluted serum, but it is essential to make sure that there is no undissolved or precipitated material in the solution applied to the filter paper. Fibrinogen is particularly liable to precipitate and it is noticeable that for this reason plasma is frequently less satisfactory to run than serum.

Formation of the Starting Boundary.-Proteins are especially liable to denaturation if dried in the presence of oxygen or if spread over a large surface area.

The practice of applying the protein solution to the dry filter paper before the paper is saturated with buffer is likely therefore to lead to erroneous results. In like manner the use of paint brushes for the application of the serum should be avoided, as the contact of the protein solution with the paint brush, presumably due to the large surface area of the bristles, leads to denaturation.

It is our practice to soak a narrow ribbon of filter paper, already damped with buffer of the $\subseteq$ same quality as that in which the serum is to be analysed, in the serum and, having quickly and lightly blotted off the excess serum with bufferdamped filter paper, to place the ribbon immediately on the buffer-saturated filter paper which is to be used for analysis in position in the box. After contact for nine minutes the ribbon is removed with forceps, the box sealed, and the current started.

For quantitative application the solution is $\frac{\circ}{\mathbb{Q}}$ applied directly to the analysis paper using a micropipette or an "agla" micrometer syringe.

The Buffer.-To produce consistent analyses the buffers used should be adequate both in bulk and buffering capacity; the volume, to limit $\mathrm{pH}$ change from the migration of ions other than those being ? investigated ; the capacity, to swamp the inherent buffering effects of the ions being investigated. Proteins themselves are powerful buffers and must $\delta$ be prevented from influencing the $p \mathrm{H}$ of the system.

The Buffer Volume.-In the classical apparatus $\rightarrow$ in which the total volume of analysed material is about $10 \mathrm{ml}$. each electrode vessel holds $1,000 \mathrm{~N}$ $\mathrm{ml}$. In the classical preparative apparatus the electrode vessel volume is swollen to $5,000 \mathrm{ml}$. N For filter-paper electrophoresis Kunkel and Tiselius $\omega$ calculated theoretically that to prevent $p \mathrm{H}$ change due to $H_{\text {ion }}$ migration over 24 hours a minimalo capacity of $313 \mathrm{ml}$. in each buffer chamber using $\Phi$ barbitone is needed. Their apparatus had buffer $\stackrel{?}{-}$ chambers of $800 \mathrm{ml}$. capacity. While it is essential $\frac{0}{0}$ to have an adequate buffer volume, $800 \mathrm{ml}$. is prob- $\frac{O}{\mathbb{D}}$ ably a handsome margin of safety; indeed, in the $\stackrel{\mathbb{\oplus}}{\mathscr{Q}}$ apparatus we use, in which the electrode chamber $\stackrel{\mathbb{Q}}{\Omega}$ is independent and linked by agar bridges to the $\overline{0}$ buffer chamber, the buffer chambers themselves, 0 into which the strips dip, have a volume of $300 \mathrm{ml}$. 
each. $p \mathrm{H}$ measurements show no $p \mathrm{H}$ shift over 24 hours using silver/silver chloride electrodes, though if carbon is substituted the $p \mathrm{H}$ shift may be as much as 0.5 of a $p H$.

In certain apparatus described by Hall (1948) and Franglen (1953) the potential buffer capacity is increased by arranging the continuous flow of buffer through the buffer chambers.

Buffer Strength.-Buffer strengths giving satisfactory resolutions of protein mixtures range between $0.04 \mathrm{M}$ and $0.15 \mathrm{M}$ depending on the type of buffer used.

Increasing the concentration beyond these limits tends to reduce the effective mobility of the proteins and so impede separation. It increases the risk of precipitation and the risk of denaturation. Increased concentration of the buffer sharpens boundaries formed by limiting diffusion.

Decreasing the buffer concentration decreases the ability of the buffer to control $p \mathrm{H}$, increases diffusion with blurring of boundaries, and tends to cause precipitation of the slower components. The optimum lies at about $0.12 \mathrm{M}-0.06 \mathrm{M}$ for barbiturate buffers at $p \mathrm{H} 8.6$ and about $0.15 \mathrm{M}-$ $0.1 \mathrm{M}$ for phosphate buffers at $p \mathrm{H}$ 8.0.

Buffer Patterns.-The choice of buffer pattern depends on the $p \mathrm{H}$ range at which the mixture is to be investigated. For most clinical purposes $p \mathrm{H} 8.6$ using barbiturate buffer or $p \mathrm{H} 8.0$ using phosphate buffer are the most suitable.

The constitution of the buffer affects the qualitative and quantitative separation of mixtures. Satisfactory comparisons cannot therefore be made between separations carried out in buffers that differ in constitution or concentration.

A simplified table of buffers we have found useful is given below (Table I). It should be noted that borate buffers, because of their capacity to form complexes, often produce unusual patterns with the $\alpha$ and $\beta$ globulins.

Maintenance of Buffer Equilibrium.-It is essential to be certain that the box in which the analyses are being carried out is completely sealed and is free from air leaks. Any air leaks produce local disturbances in equilibrium with consequent distortion and irregularity of the patterns produced.

To prevent leaks we have used plasticine, or rubber washers and a screw-capped lid, with equal success. Mercury seals are satisfactory but expensive.

Hydrostatic Equilibration.-Before the passage of current in the ideal state, the buffer pattern and concentration should be uniform in the path of the analysis. In the classical apparatus there is no difficulty in arranging a stable buffer pattern in the chambers through which the boundaries are to pass. Special considerations arise when selecting buffer systems in the presence of cellulose fibres. These will be dealt with in the section on matrices.

Temperature Control.-For current densities up to 1.0 milliamps to $4 \mathrm{~cm}$. width of strip, no appreciable temperature changes have been observed in the simpler patterns of apparatus for filter paper electrophoresis. In the apparatus we have used thermocouples embedded in the filter paper indicated a temperature fluctuation of $0.2^{\circ}$ C. at $19^{\circ}$ over 16 hours using silver/silver chloride electrodes and $1.5^{\circ} \mathrm{C}$. using carbon electrodes, the runs being conducted at 5 milliamps and 100 volts.

If higher current densities are required the apparatus described by Cremer and Tiselius (1950) and modified by Schneider and Wallenius, in which

TABLE I

USEFUL BUFFERS

\begin{tabular}{|c|c|c|c|c|c|}
\hline \multicolumn{3}{|c|}{ General Data } & \multicolumn{3}{|c|}{ Data for Specific Concentrations and $p H$ Values Named } \\
\hline Constituents & $p$ H Range & $\begin{array}{l}\text { Concentration } \\
\text { Range for } \\
\text { Electrophoresis }\end{array}$ & Buffer Formula & Concentration & $p \mathrm{H}$ at $20^{\circ} \mathrm{C}$. \\
\hline 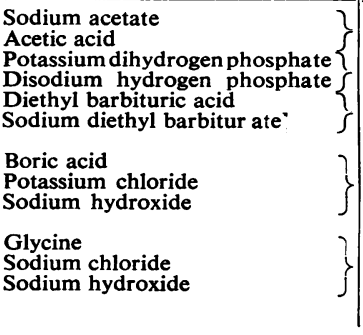 & $\begin{array}{l}4 \cdot 0-5 \cdot 5 \\
6 \cdot 0-8 \cdot 2 \\
7 \cdot 5-9 \cdot 0\end{array}$ & $\begin{array}{l}0.05-0.15 \mathrm{M} \\
0.1-0.15 \mathrm{M} \\
0.05-0.12 \mathrm{M}\end{array}$ & $\begin{array}{l}700 \mathrm{ml} . \mathrm{N} / 10 \text { sodium acetate } \\
300 \mathrm{ml} . \mathrm{N} / 10 \text { acetic acid } \\
947 \mathrm{ml} . \mathrm{M} / 10 \mathrm{Na}_{2} \mathrm{HPO}_{4} \\
53 \mathrm{ml} \text {. M } / 10 \mathrm{KH}_{2} \mathrm{PO}_{4} \\
10.3 \mathrm{~g} \text { diethylbarbituric acid } \\
1.84 \mathrm{~g} \text {. sodium diethyl barbi- } \\
\text { turate in } 1 \text { litre of water } \\
\text { (A) } 12.37 \mathrm{~g} . \mathrm{H}_{3} \mathrm{BO}_{3}, 14.91 \mathrm{~g} . \\
\mathrm{KCl} \text { both in } 1 \text { litre water } \\
\text { (B) } 428 \mathrm{ml} .4 \% \text { caustic soda } \\
\text { Add (A) to (B) and mix } \\
\text { (A) Glycine } 4.55 \mathrm{~g} ., \mathrm{NaCl} \\
3.53 \mathrm{~g} . \text { in } 600 \text { mi. } \\
\text { (B) } 0.4 \% \text { caustic soda, } 400 \mathrm{ml} . \\
\text { Add (A) to (B) and mix }\end{array}$ & $\begin{array}{l}0.1 \mathrm{M} \\
0.1 \mathrm{M} \\
0.06 \mathrm{M} \\
0.05 \mathrm{M}\end{array}$ & $\begin{array}{l}5 \cdot 0 \\
8 \cdot 0 \\
8 \cdot 6 \\
9 \cdot 0\end{array}$ \\
\hline
\end{tabular}


the paper is clamped between glass plates and the plates immersed in chlorooenzene, has proved satisfactory (Schneider and Wallenius, 1951). The modification of this technique introduced by Kunkel and Tiselius (1951), in which the glass plates are sealed in silicone grease and not plunged in chlorobenzene, has been adapted ingeniously by these authors. The whole apparatus was placed in a cold room, the glass plates resting on a brass block. By this means adequate heat dispersion was obtained and voltages from 80 to 400 volts giving current ranges from 4 to $20 \mathrm{~mA}$ were used satisfactorily. These levels approach those commonly used in the classical apparatus.

The Filter Paper Matrix.-Only the best grades of paper should be used for analysis, preferably those "for chromatography." We have found Whatman Nos. 1 and 4, Whatman 3 MM., and Munktell 20 absolutely satisfactory for all general uses. Since the rate of migration, and therefore the degree of effective separation in a given time, is affected by the texture of the paper, comparisons of analyses made on different types of paper should be avoided.

Consden and Stanier (1952b) have compared 11 grades of Whatman paper using albumin as a reference substance. Their data is given in tabular form below.

MIGRATION OF HUMAN SERUM ALBUMIN AND ELECTROENDOSMOSIS

$(\mathrm{cm}$./hr. on various Whatman papers in borate buffers $p \mathrm{H} 8.6$ at $10 \cdot 3 \mathrm{~V} / \mathrm{cm}$. at $20^{\circ} \mathrm{C}$.)

\begin{tabular}{c|c|c}
\hline Whatman No. & Electro-endosmosis & Migration of Albumin \\
\hline 1 & 0.9 & 3.2 \\
2 & 0.9 & 2.8 \\
3 & 0.9 & 3.4 \\
4 & 0.6 & $2 \cdot 8$ \\
5 & 0.4 & 2.1 \\
20 & 0.9 & 2.7 \\
42 & 0.7 & 2.4 \\
50 & 0.2 & $1.4^{*}$ \\
52 & 0.7 & $2 \cdot 1$ \\
54 & 0.8 & 2.4 \\
542 & 0.5 & $1.6^{*}$ \\
\hline
\end{tabular}

* Not measurable accurately: papers unsuitable for serum proteins.

The filter-paper matrix cannot be regarded as a neutral support medium. It carries a measurable negative charge. Many attempts have been made to neutralize this charge using gentian violet (Hauser and Lynn, 1940), " cetab" (Rutter, 1950), and albumin (Tiselius, 1953). Jermyn and Thomas (1953) have studied the endo-osmotic flow using spots of tri-nitro benzene and $O$. nitroaniline. Finally at extreme acid and alkaline $p \mathrm{H}$ ranges in the region of $p \mathrm{H} 3$ and $p \mathrm{H} 11$ the cellulose fibres themselves fragment and swell, making analysis in these regions difficult if not impossible.
Methods of Analysis.-One of the most important steps in electrophoretic analysis is the technique by which the boundaries, once established, are identified and by which the composition of the separating mixture is expressed in quantitative terms. Each method of estimation has its special difficulties, which not only define the limitations of the analysis incorporating the method, but limit the comparisons which may be made with analyses made by alternative methods.

As most of the mixtures analysed by paper electrophoresis are invisible on the supporting media, special procedures are necessary to determine the position of the separated components. Many such procedures have been described, of which a number have been adapted to give quantitative estimation of th̀e components, in addition to their localization. The most usual method of locating proteins on paper " electrophoretograms" is by visualization with dyes, either of the acid wool or of the indicator type.

The procedure commonly adopted is to remove the paper strip after completion of the electrophoretic run, taking care in removing it not to allow it to brush against the apparatus or the bench. The paper is then suspended in an oven and dried at $105^{\circ} \mathrm{C}$. for 30 minutes. The paper may then be dyed by a number of techniques. Four of these in common use in this laboratory are given in Table II.

Countless dyeing procedures, however, have been described in attempts to obtain the maximum contrast between the dyed protein and the background, and to obtain the maximum uptake of dye by the different protein fractions. These procedures have been extended to the analysis of protein separated on gels, since, by applying a piece of filter paper to the surface of the gel, a protein print is obtained which can be dyed by the usual methods (Consden, Gordon, and Martin, 1946).

Substances which can be located on the supporting medium by their fluorescence or absorbence in ultra-violet light may be identified directly (Paladini and Leloir, 1952). Attempts have been made to use such fluorescence for the quantitative estimation of separated components, and special apparatus has been designed for this purpose (Hashimoto and Mori, 1952; Semm and Fried, 1952).

Some components separated by paper electrophoresis can be located and estimated by their specific biological action. This approach has been particularly useful in the study of enzymes and hormones, activity being located either by incubation in situ with chromogenic substrates (Mills 
TABLE II

COMMONLY USED DYEING TECHNIQUES

\begin{tabular}{|c|c|c|c|c|}
\hline Dye Solutions & $\begin{array}{c}\text { Time of } \\
\text { Dyeing (min.) }\end{array}$ & Washing Solution & Drying & Adapted From \\
\hline $\begin{array}{l}\text { Bromophenol blue, } 1 \mathrm{~g} . \\
\text { EtOH sat. with } \mathrm{HgCl}_{2}, 100 \mathrm{ml} \text {. } \\
\text { Azocarmine } \mathrm{B}, 0.75 \mathrm{~g} . \\
\text { MeOH, } 50 \mathrm{ml} \text {. } \\
\text { Acetic acid glacial, } 10 \mathrm{ml} \text {. } \\
\text { Water up to } 100 \mathrm{ml} .\end{array}$ & $5-10$ & $\begin{array}{l}0.5 \% \text { acetic acid. Four successive } \\
\text { washes over } 20 \text { minutes until } \\
\text { background is clear } \\
\text { 1st wash } 90 \% \text { methyl alcohol con- } \\
\text { taining } 10 \% \text { acetic acid v/v. } \\
\text { Final wash in } 10 \% \text { acetic acid } \\
\text { in water }\end{array}$ & $\begin{array}{l}\text { Dry at lab. temp. } \\
\text { Dry at lab. temp. }\end{array}$ & $\begin{array}{l}\text { Kunkel and Tiselius, 1951 } \\
\text { (Cremer and Tiselius, 1950) } \\
\text { Plückthun and Götting, 1951 } \\
\text { (Turba and Enenkel, 1950) }\end{array}$ \\
\hline $\begin{array}{l}\text { Bromocresol green, } 0 \cdot 2 \mathrm{~g} \text {. } \\
\text { Acetic acid glacial, } 2 \mathrm{ml} \text {. } \\
95 \% \text { EtOH up to } 100 \mathrm{ml} \text {. }\end{array}$ & 10 & $\begin{array}{l}2.0 \% \text { acetic acid in water. Four } \\
\text { successive washes over } 20 \text { min- } \\
\text { utes until background is clear }\end{array}$ & $\begin{array}{l}\text { Dry at lab. temp; } \\
\text { and "blue up" } \\
\text { over conc. am- }\end{array}$ & Franglen, 1953 \\
\hline $\begin{array}{l}\text { Naphthalene black } 12 \mathrm{~B}, 0.1 \mathrm{~g} \text {. } \\
\text { Acetic acid glacial, } 10 \mathrm{ml} . \\
\text { Methyl alcohol, } 90 \% \text { to } 100 \mathrm{ml} \text {. }\end{array}$ & 10 & $\begin{array}{l}\text { 1st wash } 90 \% \text { methyl alcohol con- } \\
\text { taining } 10 \% \text { acetic acid v/v until } \\
\text { background is pale blue. 2nd } \\
\text { wash pure methyl alcohol } \\
5 \text { minutes }\end{array}$ & $\begin{array}{c}\text { monia bottle } \\
\text { Dry at lab. temp. }\end{array}$ & $\begin{array}{l}\text { Fly nn and de Mayo, } 1951 \text { (the } \\
\text { A midoschwartz 10 B of } \\
\text { Grassmann et al., 1951)! }\end{array}$ \\
\hline
\end{tabular}

Ponceau red 2R. (Röttger, 1952) and light green C.I. 670 (Smith and Dangerfield, 1954) have also proved very satisfactory.

and Smith, 1951) or by standard methods of assay after elution from the supporting medium (Kunkel, Taylor, and du Vigneaud, 1953). It is, perhaps, not superfluous to point out that, if studies of this nature are to be of real value, it is essential to check that such activity is not altered by the conditions necessary for electrophoresis.

In several methods, a component of the mixture is marked with radioactive tracers or dyes before electrophoresis, so that it can be located on the supporting medium during or after separation. Radioactive iodine (Larson, Deiss, and Albright, 1952), iron (Wallenius, 1952a), phosphate (Maurer and Schild, 1951), and labelled amino-acids (Gros, Dubert, Sung, Coursaget, and Macheboeuf, 1952) have all been incorporated into proteins to aid in their identification after separation. N-tolyl alpha-naphthylamine 3 sulphonic acid combines with albumin to give a brilliantly fluorescent complex which we have used for following the migration of albumin on filter paper. Other workers have found the dyeing of serum albumin before electrophoresis with bromophenol blue (Kunkel and Tiselius, 1951) or bilirubin (Flynn and de Mayo, 1951) a useful means of judging the degree of separation of serum proteins in cells in which the speed of separation is liable to variation. It is a little surprising to note that the mobility of these albumin complexes is not significantly different from the untreated albumin. Radioactive iodinated albumin has been reported to have a higher mobility than non-iodinated albumin (Gabrieli, Goulian, Kinersly, and Collet, 1954). These observations needed to be checked with other protein-tracer complexes, and until such checks have been completed conclusions based on pre-marking techniques must be treated with reserve.
Comparisons of the dyed protein electrophoretograms with classical Schlierin diagrams suggested to earlier workers that determination of the protein-bound dye would form a means of estimating the relative proportions of the protein fractions (Cremer and Tiselius, 1950; Flynn and de Mayo, 1951). In many of the earlier methods the dyed filter paper electrophoretogram is cut into consecutive strips of equal width from which the dye is eluted by alkaline solutions or organic solvents and measured by absorptiometry (Cremer and Tiselius, 1950; Robinson and Fehr, 1952; Loeffler and Wunderly, 1953). For accurate dye determination it is essential that fading does not occur in the eluting solution (Franglen and Martin, 1954a). Although simple in use, these elution procedures are tedious and cannot be applied to every dye.

Methods of measuring the optical density of the protein-dye complex on the paper directly were developed to overcome these shortcomings, and vary in complexity from the use of visual matching techniques (Latner and Richardson, 1952) to the use of elaborate self-recording photoelectric " scanners" (Crook, Harris, and Warren, 1952 ; Einsenreich and Eder, 1951; Grassmann, Hannig, and Knedel, 1951 ; Griffiths, 1952 ; Latner, Braithwaite, and Nunn, 1952 ; Latner, Molyneux, and Rose, 1954 ; Van Os, 1952, 1953 ; Weicker, 1953). Many of the earlier " scanning " methods, such as that of Grassmann and his co-workers, have a disadvantage in that clarification of the paper with paraffin mixtures is necessary before measurements can be made, but recently this has been overcome by the photoelectric measurement of light reflected from the dry paper (Röttger, 1953). Many of the simpler "scanners" have an inherent weakness in that no compensation is made 
for the decrease of photocell response with time, and in such cases, unless scanning is rapid, results cannot be truly reproducible. Michl has described a different method of optical evaluation based on the use of an absorption wedge with a cylindrical lens system (Michl, 1952) which, although simple, does not suffer from this defect.

Both types of dye analysis produce graphical plots which bear a superficial resemblance to Schlierin diagrams obtained on the classical apparatus (Fig. 7). Rigid comparison with

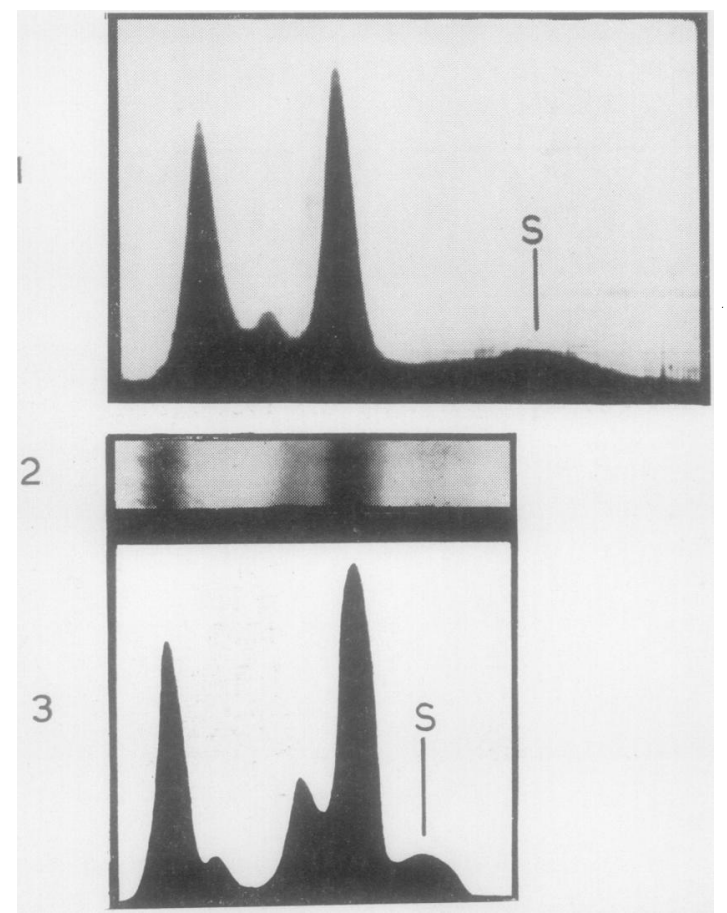

FIG. 7.-Analyses of the serum of a patient suffering from myelomatosis indicating the qualitative and quantitative differences that may occur between the classical technique and paper electrophoresis. 1 is the Schlierin pattern on the Tiselius apparatus in $0.1 \mu$ barbiturate buffer at $p \mathrm{H}$ 8.6. 2 is the " electrophoretogram" in the flat box in $0.06 \mathrm{M}$ barbiturate buffer at $p \mathrm{H} 8.6$ stained with azocarmine B. 3 is the analysis of the electrophoretogram (2) by reflected light in an automatic scanner. $S$ indicates the starting boundary in each analysis.

classical electrophoresis showed that differentiations achieved by the old method were not constantly mirrored in the new. The variations in mobilities obtained with purified fractions, whether using dextran or albumin markers, indicated that these could only form the crudest means of identification (Martin, 1952). Moreover, the distribution of dye between the separated protein fractions is not identical with the proportions of the fractions as determined by the refractive index method (Cremer and Tiselius, 1950). A great deal of effort has gone into devising correction factors or modifications which would enable analyses by the younger method to approximate to the older (Cremer and Tiselius, 1950 ; Köiw, Wallenius, and Grönwall, 1951, 1952 ; Kunkel and Tiselius, 1951 ; Levin and Oberholzer, 1953; Schneider, 1951), and many procedures of determining serum and other protein fractions by dye estimation have been described (Antonini and Piva, 1952; Esser, Heinzler, Kazmeier, and Scholtan, 1951 ; Goa, 1951 ; Grassmann et al., 1951 ; Körver, 1950 ; Loomeijer, 1952 ; Michl, 1951, 1952 ; Noverraz, 1952; Plückthun and Götting, 1951 ; Vignato, 1952 ; Vishnyakov, Dobrovol'skii, Ermakov, and Tuckachinskii, 1952).

These procedures assume primarily that all the proteins examined will interact with the chosen dye, that the dye uptake bears a simple relationship to the protein concentration, and that the dye-binding capacities of the different fractions, although not necessarily identical, will bear a simple consistent relationship to each other at all concentrations at which each component is met. Unfortunately none of these assumptions has proved to be true ; " correction factors" may vary by several hundred per cent, and the uptake of dye is not always a linear function of protein concentration (Figs. 8a and 8b) (Köiw et al., 1952; Grönwall, 1952 ; Crook, Harris, Hassan, and Warren, 1954 ; Franglen and Martin, 1954b). Moreover, since dye samples often vary considerably in composition from maker to maker and from batch to batch (Tudor Jones in a paper read before the Fine Chemicals Group of the Society of the Chemical Industry on January 15,1954 ) it is unlikely that correction factors will remain constant for any one dye even with rigorously controlled protein concentrations. It must be concluded therefore that the present dye methods are not generally suitable for the accurate estimation of protein fractions. At the same time, this does not prevent these methods continuing to be of clinical value in indicating gross changes in individual protein components.

In order to eliminate the uncertainties inherent in the analysis of proteins by dyeing procedures, other methods of analysis have been described. Nitrogen determinations on the separated protein fraction by Kjeldahls have been undertaken by some workers (Anderson, 1952 ; Levin and Oberholzer, 1952, 1953). Since the quantity of protein nitrogen involved is small, electrophoresis of the serum is usually carried out in non-nitrogenous buffers, such as phosphate or borate, in which fractionation tends to be poor. Although the accuracy claimed for these procedures is high, their tediousness does not recommend them for general use 
Kunkel and Tiselius (1951) have adapted the Heidelberger and MacPherson (1943) procedure for the determination of tyrosine to the estimation of proteins separated by paper electrophoresis. The use of Folin's reagent as a means of quantitative assessment of individual proteins has been criticized on the basis of the known variations in tyrosine content that occurs between different protein species (Martin, 1952). The phenomenon of

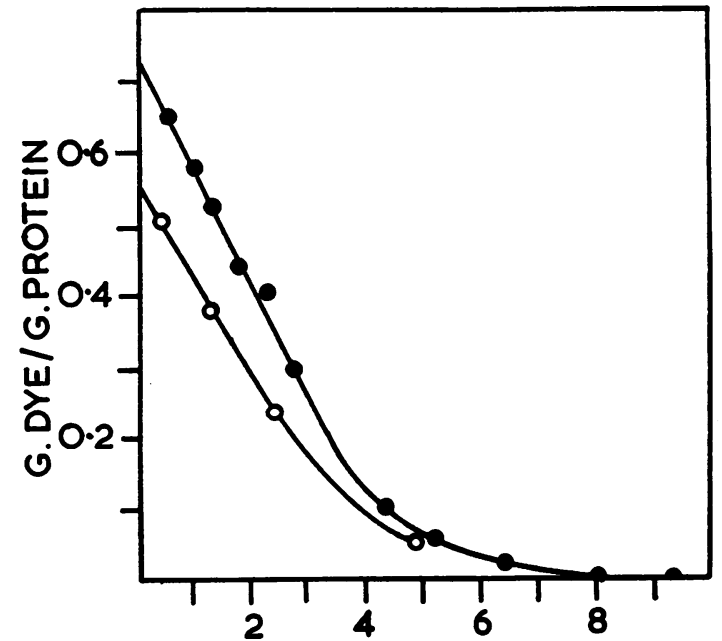

PROTEIN CONC. G./1OOML. Fig. 8a.

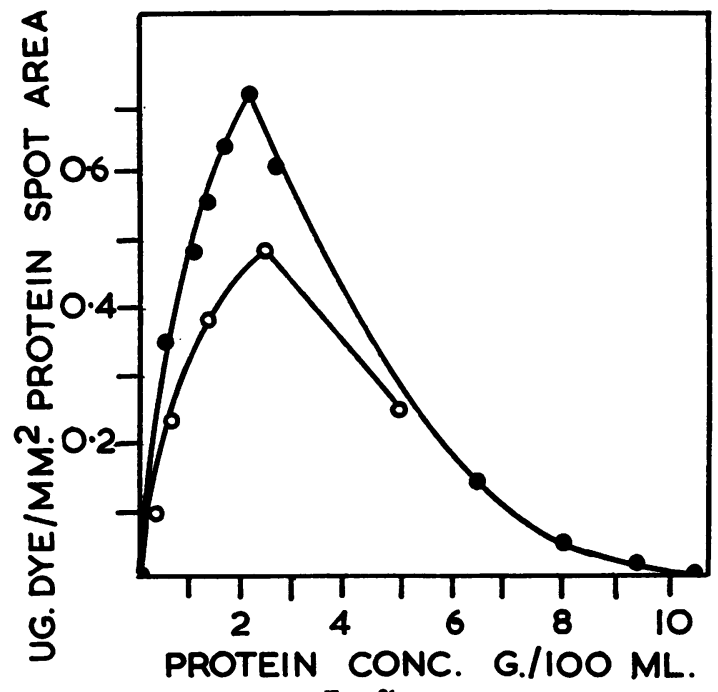

FIG. 8 b.

Fig. $8 \mathrm{a}$ and $8 \mathrm{~b}$.-Curves of the uptake of bromo cresol-green by human proteins on paper. Fig. $8 \mathrm{a}$ illustrates that using elution methods the uptake of dye by unit weight of protein is not constant. Fig. $8 \mathrm{~b}$ illustrates that the uptake of dye by unit area of protein (the basis of scanning techniques) only varies directly with protein concentration at low concentrations. $-0-0-0-\gamma$ with protein concentration at
globulin. - $-0-$ albumin. ion retention has been used for the analysis of protein and other types of electrophoretograms (Wieland, 1948; Wieland and Fischer, 1948 ; Wieland and Wirth, 1950 ; Robinson and Fehr, 1952). In analysis by this method the edge of the electrophoretogram parallel to the direction of migration is dipped into a coloured solution

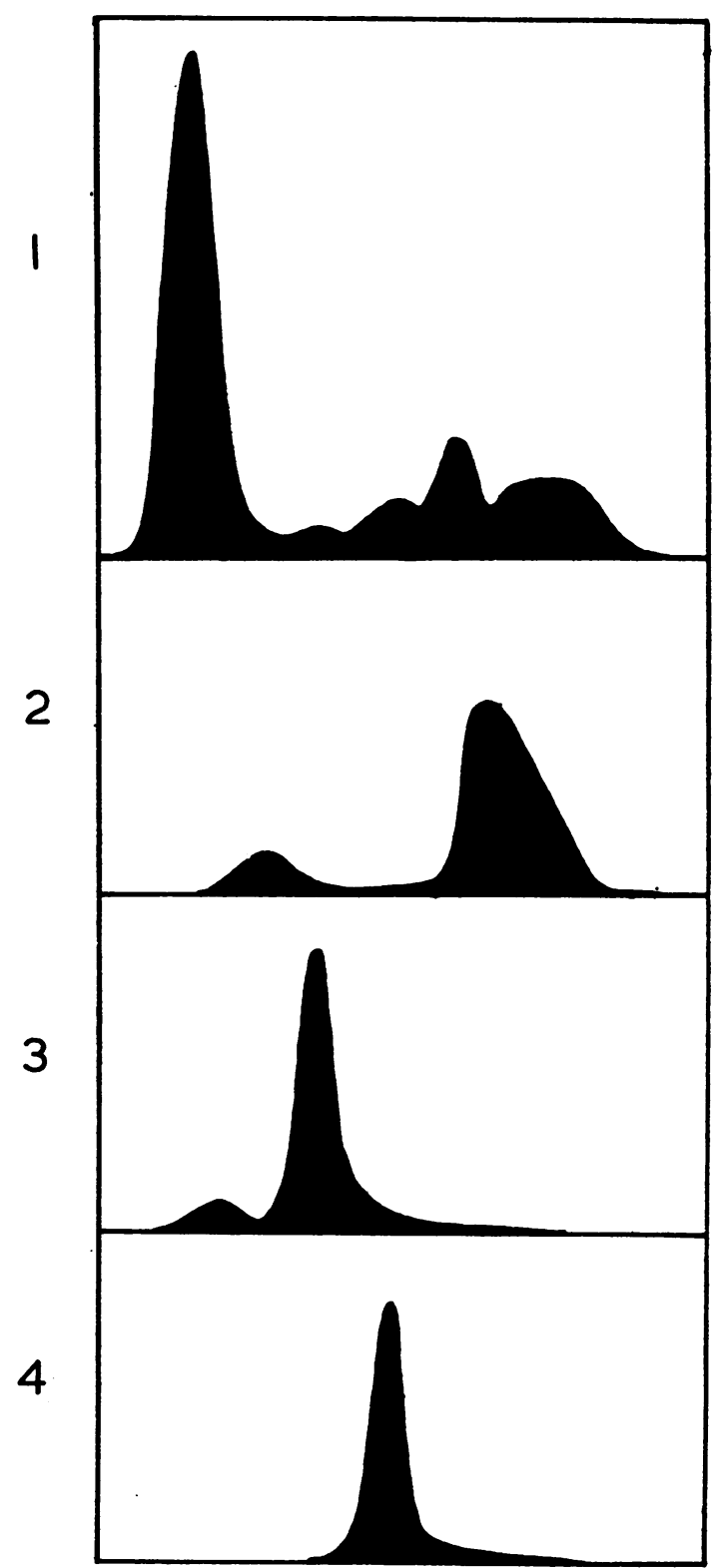

FIG. 9.-Serial analyses of a normal serum showing the position in the protein mosaic of some of the constituents. $1=$ the serum proteins, $2=$ the lipoproteins, $3=$ the distribution of radioactive odine, $4=$ the distribution of radioactive iron. 
such as that of copper acetate, erythrosine, or Solway purple. As the solution is soaked up by the paper, the coloured component combines with the protein, causing the formation of an irregular front. The areas of the irregularities are claimed to be simply related to the protein present, but Robinson and Fehr (1952) have shown that such relationships cannot be found with all proteins, and, in our experience, results obtained by retention analysis are very approximate, and tend to be less satisfactory than those obtained by a visual inspection of the dyed electrophoretogram.

Visualization of lipid fractions (Fig. 9) have been reported by several workers (Nikkilä, 1952 ; Swahn, 1952 ; Wunderly and Pezold, 1952). Both Sudan III (Fasoli, 1952, 1953 ; Kunkel and Slater, 1952a) and oil red O (Durrum, Paul, and Smith, 1952) have been used, and we have found Sudan black to be very satisfactory. It must be pointed out, however, that fat stains are notoriously variable in reaction, and we have had several batches of dyes which have proved to be quite useless for staining lipid on paper. In connexion with this class of substances, it should be mentioned that Kunkel and Slater found that the fractionation of serum lipid was improved by the use of buffers of low ionic strength or by the use of starch in place of paper as a supporting medium.

Protein-bound carbohydrates have been visualized by a procedure involving the use of Schiff's reagent (Köiw and Grönwall, 1952).

Other substances have been analysed by techniques originally developed for paper chromatography. These include amino-acids and peptides (Biserte, 1950 ; Consden and Gordon, 1950 ; Durrum, 1950, 1951c ; Kickhöfen and Westphal, 1952 ; McDonald et al., 1951a and b ; Michl, 1951 ; Reindel and Hoppe, 1953 ; Suzuki and Maekawa, 1951) and carbohydrates (Consden and Stanier, 1952b ; Foster, 1953 ; Foster and Stacey, 1953 ; Gross, 1953).

Applications.-For brevity we have used tables (Tables III, IV, and V) to give some indication of the way in which the technique has been applied. The tables speak for themselves, and it is only necessary to comment on pitfalls and limitations in routine use.

Qualitative and semi-qualitative analysis of protein-containing fluids can be made effectively by the method if the protein concentration is above $2 \%$, provided care is taken to remove all insoluble material and to remove excess of soluble salts either by dialysis or by desalting (for details of the technique see Consden et al., 1947). Any procedures carried out on protein solutions at room temperatures are liable to cause some denaturation. Extreme caution is therefore needed in interpreting subsequent analyses unless the most scrupulous precautions can be and are taken. We do not believe that desalting is a technique suitable for routine laboratories, nor that the number of times it is needed would justify the expense of the apparatus. For most protein-containing fluids dialysis is sufficient.

For protein solutions below $2 \mathrm{~g}$. per $100 \mathrm{ml}$. some form of concentration is usually desirable. Three relatively simple methods are available, ultrafiltration, dialysis against strong solutions of dextran or some other suitable polymer, or acetone precipitation. The last method is undesirable because of the very great risk of denaturation. The choice between the first two depends on convenience and the amount of available material.

All methods involve a considerable expenditure of time and skilled labour if the results obtained are to be consistent and reliable. It is doubtful, in the present state of knowledge, whether the useful information they give is so far in advance of that obtained by older and simpler techniques as to justify their regular use in the majority of routine clinical pathological laboratories.

We have observed discrepancies repeatedly between analysis by the classical technique and by paper electrophoresis. We believe that the classification of any disease on the basis of analyses that show such inconsistency is a fruitless procedure until more is known of the factors which produce these inconsistencies.

\section{Conclusions}

Because of the more meticulous approach to the classical technique initiated by the pioneer work of Tiselius, chaos has not and is not likely to occur using that method. Its great value is likely to remain as a tool of research and reference. Because of its cost, the amount of material required for analysis, and the time taken for each analysis, it will probably remain an unsuitable technique for the majority of routine clinical laboratories in the foreseeable future. For biological problems where limited material is available, multiple analyses are required, and speed is a consideration, the method of electrophoresis using paper seems admirably suited.

It is unlikely in our present state of knowledge that all the theoretical requirements can be met by any one design, but that should not be made a bar to progress, nor should it be an excuse for neglecting those requirements which can be met with reasonable simplicity. 
TABLE III

ANALYSES OF CLINICAL SUBSTANCES

\begin{tabular}{|c|c|c|c|}
\hline Substance & Supporting Medium & Method of Analysis & References \\
\hline $\begin{array}{l}\text { Normal and pathological } \\
\text { serum proteins }\end{array}$ & Paper & Dyes & $\begin{array}{l}\text { Flynn and de Mayo (1951); Köiw et al. (1951); Macheboeuf et } \\
\text { al. (1951); Gras (1952); Köiw and Grönwall (1952); Loomeijer } \\
\text { (1952); Noverraz (1952); Sternberg (1953); Wunderly (1953) }\end{array}$ \\
\hline $\begin{array}{l}\text { Serum proteins in mul- } \\
\text { tiple myelomatosis }\end{array}$ & , & $\begin{array}{l}\text { Dyeing with bromo- } \\
\text { phenol blue }\end{array}$ & Griffiths and Brews (1953)-a study of 20 cases \\
\hline $\begin{array}{l}\text { Serum proteins in liver } \\
\text { and bile disease }\end{array}$ & ", & Bromophenol blue & Brante (1952) \\
\hline $\begin{array}{l}\text { Cerebrospinal fluid pro- } \\
\text { teins }\end{array}$ & ", & Dyes & $\begin{array}{l}\text { Schneider and Wallenius (1951) concentration by dialysis against } \\
\text { dextran solutions; Bucher et al. (1952a and b) concentration by } \\
\text { acetone precipitation of protein; Caspani (1952); Esser and } \\
\text { Heinzler (1952) concentration by ultrafiltration; Esser et al. } \\
\text { (1952); Wallenius (1952b) normal and pathological c.s.f.; Mies } \\
\text { (1953); Peters (1953); Plückthun and Matthes (1953) } \\
\text { Macheboeuf et al. (1951); Slater and Kunkel (1953); Squire (1953) } \\
\text { distribution and clearance of protein in nephritis }\end{array}$ \\
\hline $\begin{array}{l}\text { Lipoproteins } \ldots \\
\text { Serum protein-bound car- } \\
\text { bohydrates }\end{array}$ & Paper and starch & $\begin{array}{l}\text { Lipid dyes } \\
\text { Schiff's reagent }\end{array}$ & $\begin{array}{l}\text { Durrum et al. (1952); Fasoli (1952, 1953); Kunkel and Slater } \\
\text { (1952a) use of starch as a supporting medium; Nikkilä (1952); } \\
\text { Swahn (1952); Wunderly and Pezold (1952) } \\
\text { Köiw and Grönwall (1952) }\end{array}$ \\
\hline
\end{tabular}

TABLE IVa

MISCELLANEOUS ANALYSIS OF CLINICAL INTEREST (a)

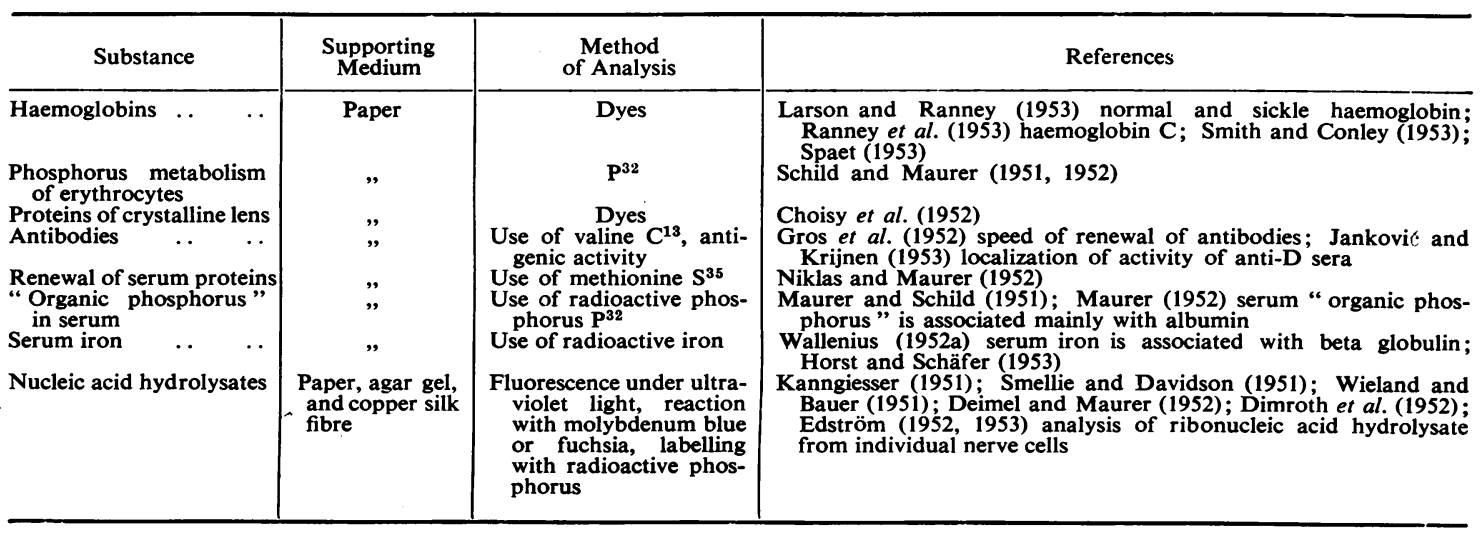

TABLE IVb

MISCELLANEOUS ANALYSIS OF CLINICAL INTEREST (b)

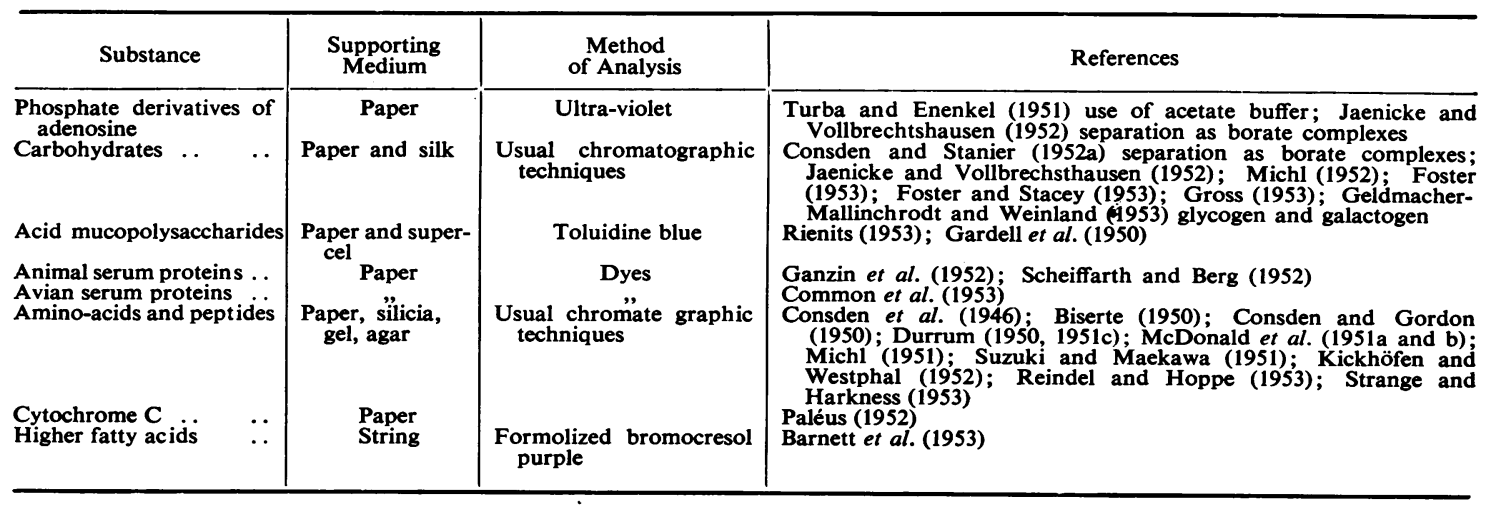


TABLE Va

BIOLOGICALLY ACTIVE SUBSTANCES OF CLINICAL INTEREST (1)

\begin{tabular}{|c|c|c|c|c|}
\hline \multicolumn{2}{|l|}{ Substance } & $\begin{array}{l}\text { Supporting } \\
\text { Medium }\end{array}$ & $\begin{array}{l}\text { Method } \\
\text { of Analysis }\end{array}$ & References \\
\hline \multicolumn{2}{|l|}{ Enzymes in cell extracts } & Paper & Biological activity & $\begin{array}{l}\text { Wallenfels and Pechmann (1951) analysis of amylases, proteinases, } \\
\text { lipases and phosphatases; Gillespie et al. (1952) analysis of } \\
\text { esterases and amylases }\end{array}$ \\
\hline Digestive enzymes & $\cdots$ & , & " $\quad$ " & $\begin{array}{l}\text { Merten et al. (1952) analysis of pepsin; Nikkilä et al. (1952) analysis } \\
\text { of trypsin; Heinrich (1953) analysis of pepsin }\end{array}$ \\
\hline Serum cholinesterase & $\cdots$ & ", & $\begin{array}{l}\text { Biological activity and } \\
\text { chromogenic substrates }\end{array}$ & $\begin{array}{l}\text { Kekwick (1953) cholinesterase activity associated with at least two } \\
\text { of the serum protein fractions }\end{array}$ \\
\hline Beta-glucuronidase & . & Paper and agar & Chromogenic substrates & Mills and Smith (1951) \\
\hline $\begin{array}{ll}\text { Hyaluronidase } & \ldots \\
\text { Vitamin } \mathbf{B}_{12} & \cdots\end{array}$ & $\begin{array}{l}\cdots \\
\cdots\end{array}$ & Paper & $\begin{array}{l}\text { Staining and activity } \\
\text { Biological assay }\end{array}$ & $\begin{array}{l}\text { Caputo (1954) separation of hyaluronidase from inactive impurities } \\
\text { Latner et al. (1952) vitamin } B_{12} \text { in serum; Schweitzer and Wittern }\end{array}$ \\
\hline $\begin{array}{l}\text { Growth factors } \\
\text { Pituitary extracts }\end{array}$ & 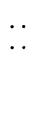 & Paper," starch & Dyes,"activity" & $\begin{array}{l}\text { Ericson et al. (1952) factors for various lactobacilli } \\
\text { Michl et al. (1951); Li (1952) A.C.T.H. preparations consist of } \\
\text { several different fractions; McDonald and Marbach (1952); } \\
\text { Kunkel et al. (1953) oxytocin; Loomeijer and Witter (1953); } \\
\text { Thing et al. (1953); Li et al. (1954) }\end{array}$ \\
\hline
\end{tabular}

TABLE Vb

BIOLOGICALLY ACTIVE SUBSTANCES OF CLINICAL INTEREST (2)

\begin{tabular}{|c|c|c|c|c|c|}
\hline \multicolumn{3}{|c|}{ Substance } & $\begin{array}{l}\text { Supporting } \\
\text { Medium }\end{array}$ & $\begin{array}{l}\text { Method } \\
\text { of Analysis }\end{array}$ & References \\
\hline \multicolumn{3}{|c|}{$\begin{array}{l}\text { Circulating thyroid hor- } \\
\text { mone }\end{array}$} & \multirow[t]{2}{*}{$\begin{array}{c}\text { Paper and starch } \\
\text { Paper }\end{array}$} & Radioactive iodine & \multirow{6}{*}{$\begin{array}{l}\text { Deiss et al. (1952) i.v. iodine is associated with slow-moving albumin } \\
\text { and alpha one globulin; Larson et al. (1952, 1954) iodine asso- } \\
\text { ciated with alpha one globulin is in the form of thyroxin; Gordon } \\
\text { et al. (1952); Maurer and Reichenbach (1952); Robbins and } \\
\text { Rall (1952); Horst and Rösler (1953) } \\
\text { Hosoya et al. (1951); Kutzim (1952a and b) analysis of sulphon- } \\
\text { amides; Foster and Ashton (1953) streptomycins; King and } \\
\text { Doery (1953) } \\
\text { Porath (1952) purification } \\
\text { Hammarlund and Rising (1953) separation from partially purified } \\
\text { antibacterial mixture } \\
\text { Gray (1952) } \\
\text { Field and Teague (1907); Poulik (1952) } \\
\text { von Klobusitzky and König (1939) separation of yellow pigment } \\
\text { from snake venom; Grassmann (1951) fractionation of five } \\
\text { protein-like components in snake toxin } \\
\text { Wieland, Wirth, and Fischer (1949); Neumann and Habermann } \\
\text { (1952) }\end{array}$} \\
\hline Antibiotics & . & $\cdots$ & & Reactivity & \\
\hline $\begin{array}{l}\text { Bacitracin } \\
\text { Madronin }\end{array}$ & & $\begin{array}{l}\cdots \\
\cdots\end{array}$ & Agä gel & ", & \\
\hline $\begin{array}{l}\text { Plant viruses } \\
\text { Diphtheria tox } \\
\text { toxin }\end{array}$ & & & $\underset{\text { paper }}{\text { Agar gel and }}$ & $"$ & \\
\hline Snake toxin & . & $\ldots$ & Paper & Visual inspection and dyes & \\
\hline Animal toxins & $\cdots$ & $\cdots$ & , & Activity & \\
\hline
\end{tabular}

It is within the capacity of any laboratory to use and maintain simple reversible electrodes. By proper planning of work, time can be allotted in any laboratory for buffer equilibriums to be established before protein boundaries are made and the run started. With a simple apparatus reasonable and reproducible qualitative comparison can be obtained between successive analyses (Fig. 10). But equally, neglect of fundamental principles will result in the production of unusual results arising from the technique and not the sample examined.

So much for the procedure of separation. The analysis of the separated components is more diffcult, but if too much is not made of the quantitative aspect of the results, useful diagnostic information can regularly be obtained by the simple procedure of scanning a normal serum with each batch of unknowns and confining reports to semiquantitative comments.

The section on applications will have indicated the potential range of usefulness in fields of research. It may be assumed that research workers will apply and describe their own rigorous checks and controls for each problem as it arises.

It is difficult in such a brief review to give weight to all aspects of the subject. It is hoped that this survey with its appended bibliography will be some help to those interested in this fascinating field and will warn others of the pitfalls.

We wish to acknowledge financial support from the research funds of St. George's Hospital for assistance with much of the original work described in this paper. 


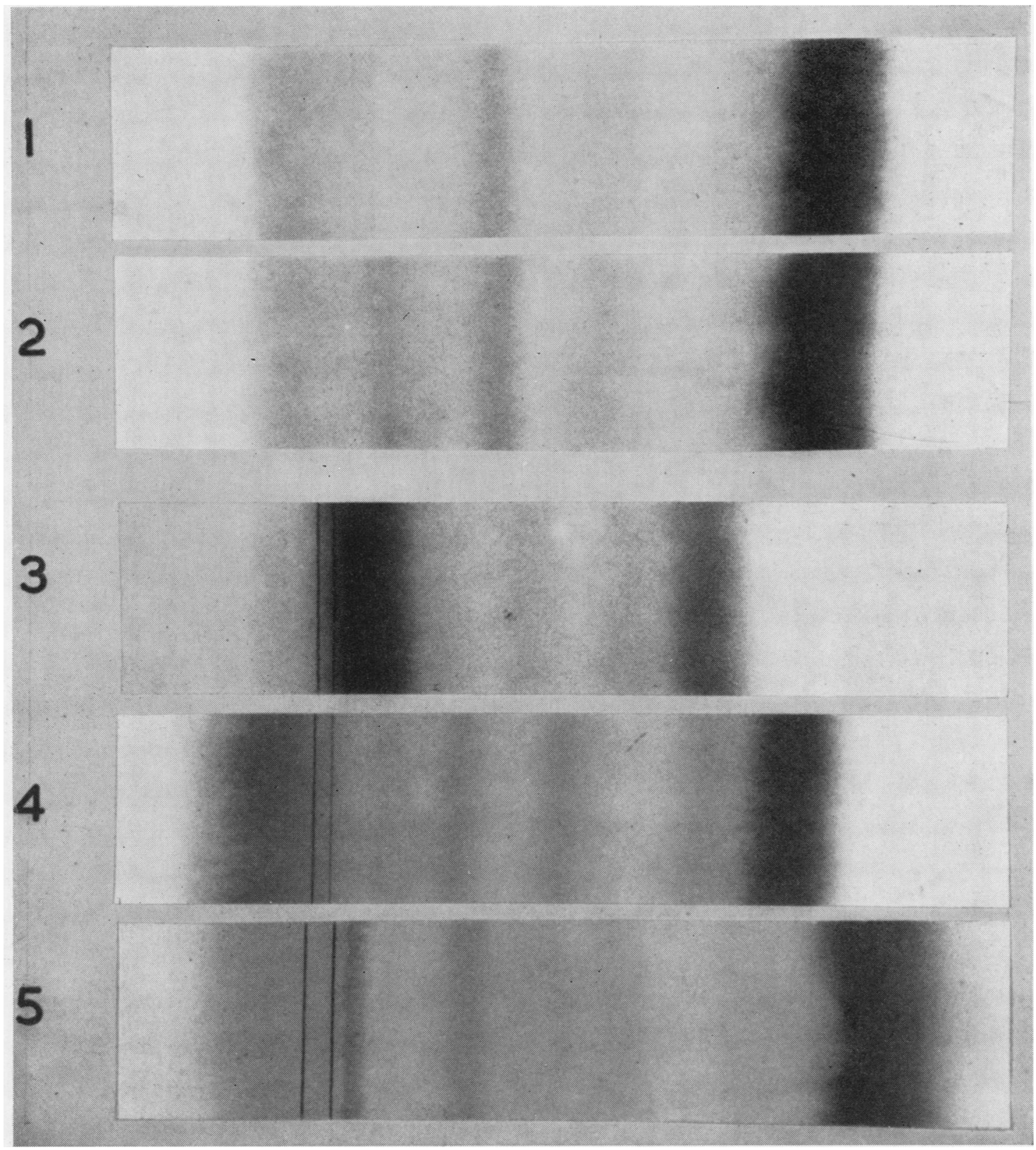

FIG. 10.-Analysis of normal and abnormal human circulating proteins using the filter paper technique on the flat box. $1=$ normal serum, $2=$ normal plasma, $3=\gamma$ type multiple myeloma serum, $4=$ chronic lymphatic leukaemia serum, $5=$ hypercholesterolaemia serum. 


\section{REFERENCES}

Alberty, R. A. (1948). J. chem. Educ., 25, 426.

Alexander, A. E., and Saggers, L. (1948). J. sci. Instrum., 25, 374. Anderson, A. B. (1952). Biochem. J., 52, x.

Antonini, F. M., and Piva, G. (1952). Boll. Soc. ital. Biol. sper., 28, 764, 1885.

Antweiler, H. J. (1947). Angew. Chem. A, 59, 33.

Antweiler, H. Jolloidzschr., 115, 130

Barnett, A. J. G., Lees, H., and Smith, D. K. (1953). Biochem. J., 53, xxxiii.

Biserte, G. (1950). Biochim. biophys. Acta, 4, 416

Brante, G. (1952). Scand. J. clin. Lab. Invest., 4, 293.

Brattsten, J and Nilsson, A. (1951). Ark. Kemi., 3, 337.

Bücher, T., Matzelt, D., and Pette, D. (1952a). Klin. Wschr., 30, 325.

$-\longrightarrow$ (1952b). Naturwissenschaften, 39, 114.

Burton, E. F. (1906). Phil. Mag. (6), 11, 425.

Caputo, A. (1954). Nature, Lond., 173, 358.

Caspani, R. (1952). Minerva med., Torino (parte sci.), 43 (1), 1346.

Choisy, A., Derrien, Y., and Jayle, G. (1952). C.R. Acad. Sci., Paris, 234, 1918.

Common, R. H., McKinley, W. P., and Maw, W. A. (1953). Science, 118, 86.

Consden, R., and Gordon, A. H. (1950). Biochem. J., 46, 8.

- and Martin, A. J. P. (1946). Ibid., 40, 33. - (1947). Ibid., 41, 590

- and Stanier, W. M. (1952a). Nature, Lond., 169, 783.

- (1952b). Ibid. 170, 1069 .

Cremer, H. D., and Tiselius, A. (1950). Biochem. Z., 320, 273.

Crook, E. M., El-Marsafy, M. K., Shooter, E. M., and Ward, F. B. (1952). Proc. biochem. Soc., March 12.

- Harris, H., and Warren, F. L. (1952). Biochem. J., 51, xxvi.

Deimel, M. D., and Maurer, M. (1952). Naturwissenschaften, 39, 489.

Deiss, W. P., Albright, E. C., and Larson, F. C. (1952). J. clin. Invest., 31, 1000.

Dimroth, K Jaenicke, L., and Vollbrechtshausen, I. (1952). HoppeSeyl. Z., physiol. Chem., 289, 71.

Dorn, E. (1880). Ann. Phys., Lpz., 10, 46.

Durrum, E. L. (1950). J. Amer. chem. Soc., 72, 2943.

- (1951a). Ibid., 73, 4875 .

(1951b). Science, 113, 66.

(1951c). J. Colloid Sci., 6, 274.

Paul, M. H. and Smith, E. R. B. (1952). Science, 116, 428.

Edström, J. E. (1952). Biochim. biophys. Acta, 9, 528.

- (1953). Nature, Lond., 172, 809.

Eisenreich, F., and Eder, M. (1951). Klin. Wschr., 29, 60.

Ericson, L. E., Bánhidi, Z. G., and Gasparetto, G. (1952). Acta chem. scand. 6, 1130 .

Esser, H., and Heinzler, F. (1952). Klin. Wschr., 30, 600. Kazmeier, F., and Scholtan, W. (1951). Münch. med. Wschr., 93, 985 .

Fasoli, A. (1952). Lancet, 1, 106

(1953). Acta med. scand., 145, 233

Field, C. W., and Teague, O. (1907). J. exp. Med., 9, 86

Flodin, P., and Porath, J. (1954). Biochim. biophys. Acta, 13, 175

Flynn, F. V., and Mayo, P. de (1951). Lancet, 2, 235.

Foster, A. B. (1952). Chem. and Industry, p. 1050

Foster, (1953). J. chem. Soc., p. 982

- and Stacey, M. (1953).' J. appl. Chem., 3, 19.

Foster, M. C., and Ashton, G. C. (1953). Nature, Lond., 172, 959.

Franglen, G. T. (1953). Journal of Clinical Pathology, 6, 183

- and Martin, N. H. (1954a). In the press.

Gabrieli, E. R., Goulian, D., Kinersly, T., and Collet, R. (1954) J. clin. Invest., 33, 136

Ganzin, M., Macheboeuf, M., and Rebeyrotte, P. (1952). Bull. Soc. Chim. biol., Paris, 34, 26.

Gardell, S., Gordon, A. H., and Åqvist, S. (1950). Acta chem. scand., 4, 907 .

Geldmacher-Mallinckrodt, M., and Weinland, H. (1953). HoppeSevl. Z. physiol. Chem., 292, 65

Gillespie, J. M., Jermyn, M. A., and Woods, E. F. (1952). Nature, Lond 169, 487.

Goa, J. (1951). Scand. J. clin. Lab. Invest., 3, 236.

Gordon, A. H., Gross, J., O'Connor, D., and Pitt-Rivers. R. (1952). Nature, Lond., $169,19$.

Keil, B., and Sebesta, K. (1949). Ibid., 164, 498.

Gralén, N.. and Svedberg, T. (1941). Naturwissenschaften, 29, 270

Gras, J. (1952). Rev. esp. Fisiol., 8, 59.

Grassmann, W. (1951). Naturwissenschaften, 33, 200.

Grand Hannig, K. (1950). Ibid., 37, 397.

(1952) Hoppe-Seyl. Z, physiol. Chem $290,1$. and Knedel, M. (1951). Dtsch. med. Wschr., 76, 333.

Gray, R. A. (1952). Arch. Biochem., 38, 305.

Gray, R. A. (1952). Arch. Biochem., 38, 305. Pathology, 5, 294.

Griffiths, L. L. (1952). Journal of Clinical Path

Grönwall, A. (1952). Scand. J. clin. Lab. Invest., 4, 270

Gros, P., Dubert, J. M., Sung, S. S., Coursaget, J., and Macheboeuf, M. (1952). Bull. Soc. Chim. biol., Paris, 34, 37.

Gross, D. (1953). Nature, Lond., 172, 908.

Gutfreund, H. (1943). Biochem. J., 37, 186.
Hall, D. A. (1948). Nature, Lond., 162, 105.

Hammarlund, E. R., and Rising, L. W. (1953). J. Amer. pharm. Ass. (Sci. ed.), 42, 431

Hashimoto, Y., and Mori, I. (1952). Nature, Lond., 170, 1024.

Haugaard, G., and Kroner, T. D. (1948). J. Amer. chem. Soc., 70, 2135 .

Hauser, E. A., and Lynn, J. E. (1940). Experiments in Colloid Chemistry, p. 42. McGraw-Hill Book Co., New York.

Heidelberger, M., and MacPherson, C. F. C. (1943). Science, 97, $405 ; 98,63$.

Heinrich, W. D. (1953). Biochem. Z., 323, 469.

Hoch, H. (1950). Biochem. J., 46, 199, 539.

Horst. W., and Rösler H. (1953). Klin. Wschr., 31, 13.

${ }_{\text {Hosoya }}$ and Schäfer, K. H. (1953). Ibid., 31, 340.. ., Sonoda, Y., and Arai, R. (1951). J. Antibiot., 4, 314.

Jaenicke, L., and Vollbrechtshausen, I. (1952). Naturwissenschaften, $39,86$.

Jankovié, B. D., and Krijnen, H. W. (1953). Nature, Lond., 171, 982.

Jermyn, M. A., and Thomas, R. (1953). Ibid., 172, 729.

Kanngiesser, W.. (1951). Naturwissenschaften, 38, 503.

Kekwick, R. A., Lyttleton, J. W., Brewer, E., and Dreblow, E. S. (1951). Biochem. J., 49, 253 .

Kekwick, R. G. O. (1953). Unpublished results.

Kickhöfen, B., and Westphal, O. (1952). Z. Naturf., 7B, 655.

King, N. K., and Doery, H. M. (1953). Nature, Lond., 171, 878.

Klobusitzky, D. von, and König, P. (1939). Arch. exp. Path. Pharmak., 192, 271.

Köiw, E., and Grönwall, A. (1952). Scand. J. clin. Lab. Invest., 4 244.

Wallenius, G., and Grönwal!, A. (1951). Bull. Soc. Chim. biol., Paris, 33, 1940.

- (1952). Scand. J. clin. Lab. Invest., 4, 47.

Körver, G. (1950). Klin. W'schr., 28, 693.

Kunkel, H. G., and Slater, R. J. (1952a). J. clin. Invest., 31, 677.

- (1952b). Proc. Soc. exp. Biol., N.Y., 80, 42.

Taylor, S. P., and Vigneaud, V. du (1953). J. biol. Chem. $200,559$.

Kutzim, H. (1952a). Klin. Wschr., 30, 852.

- (1952b). Naturwissenschaften, 37, 135 .

Larson, D. L., and Ranney, H. M. (1953). J. clin. Invest., 32, 1070

Larson, F. C., Deiss, W. P., and Albright, E. C. (1952). Science, $115,626$.

(1954). J. clin. Invest., 33, 230.

Latner, A. L. (1952). Biochem. J., 51, xii.

- and Richardson, M. W. (1952) Ibid., 51, xxxi.

- Braithwaite, F., and Nunn, R. A. (1952). Ibid., 51, x.

Molyneux, L., and Rose, J. D. (1954). J. Lab. clin. Med., 43, 157.

Raine, L., Ross, G. I. M., and Ungley, C. C. (1952), Biochem $J$., 52, xxxiii.

Levin, B., and Oberholzer, V. G. (1952). Nature, Lond., 17J, 123.

Levin, B., (1953). Amer. J. clin. Path., 23, 205.

Li, C. H. (1952). Acta endocr., Kbh., 10, 255.

Geschwind, I. I., Levy, A. L., Harris, J. I., Dixon, J. S., Pon, N. G., and Porath, J. O.. (1954). Nature, Lond., 173, 251.

Loeffier, W., and Wunderly, C. (1953). Journal of Clinical Pathology 6, 282.

Longsworth, L. G. (1942)_Chem. Rev., 30, 323.

Loomeijer, F. J. (1952). Ned. T. Geneesk., 96, 2360.

Loomeijer, Witter, A. (1953). Acta endocr., Kbh., 12, 167.

and

Rebeyrotte, P., and Brunerie, M. (1951). Bull. Soc. Chim. biol., Paris, 33, 1543.

Maclagan, N. F., and Bunn, D. (1947). Biochem. J., 41, 580.

Martin, N. H. (1952). Lancet, 2, 762.

Maurer, W. (1952). Klin. Wschr., 30, 323.

Maurer, Reichenbach, L (1952). Naturwissenschaften, 39, 261.

and Reichente K. T. (1951). Klin. Wschr., 29, 5il.
McDonald, H. J., and Marbach, E. P. (1952). J. Amer. chem. 'Soc., N 74, 1619 .

Urbin, M. C., and Williamson, M. B. (1951a). J. Colloid Sci., 6, 236.

(1951b). J. Amer. chem. Soc., 73, 1893.

Schramm, G., Grassmann, W., and Hannig, K. (1952). Hoppe-Seyl. Z. physiol. Chem., 289, 173.

Michl, H. (1951). Mh. Chem., 82, 489, 944.

(1952). Ibid., 83, 210, 737 .

(1952). Ibid., 83, 210, 737. (1951). Ibid., 82, 539

Mies, H. J. (1953). Klin. Wschr., 31, i59.

Mills, G. T., and Smith, E. E. B.'(1951). Biochem. J., 49, vi.

Moore, D. H., and White, J. U. (1948). Rev. sci. Instrum., 19, 700.

Neumann, W., and Habermann, E. (1952). Naturwissenschaften, 39, 286.

Nielsen, L. E., and Kirkwood, J. G. (1946). J. Amer. chem. Soc., $68,181$.

Niklas, and Maurer, W. (1952). Naturwissenschaften, 33, 260.

Nikkilä, E. (1952). Ann. Med. exp. Biol. Fenn., 30, 331 .

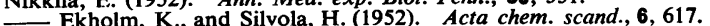

Noverraz, M. (1952). Schweiz. med. Wschr., 82, 880.

Paladini, A. C., and Leloir, L. F. (1952). Analyt. Chem., 24, 1024. 
Pal 'us, S. (1952). Acta chem. scand., 6, 969.

Peters, H. J. (1953). Chem. Weekbl., 49, 248.

Philpot, J. St L. (1938). Nature, Lond., 141, 283.

Plückthun, H., and Götting, H. (1951). Klin. Wschr., 29, 415.

and Matthes, A. (1953). Z. Kinderheilk., 72, 521.

Porath, J. (1952). Acta chem. scand., 6, 1237.

Poulik, M. D. (1952). Canad. J. med. Sci., 30, 417.

Quincke, G. (1859). Ann. Phys., Lpz., 107, 1.

- (1861). Ibid., 113, 513.

Ranney, H. M., Larson, D. L., and McCormack, G. H. (1953). J. clin. Invest., 32, 1277.

Reindel, F., and Hoppe, W. (1953). Naturwissenschaften, 40, 221.

Reuss, F. F. (1809). Mém. Soc. Impériale des Naturalistes de Moscou, 2, 327.

Rienits, K. G. (1953). Biochem. J., 53, 79.

Robbins, J., and Rall, J. E. (1952). Proc. Soc. exp. Biol., N.Y., 81, 530.

Robinson, F. A., and Fehr, K. L. A. (1952). Biochem. J., 51, 298.

Röttger, H. (1952). Naturwissenschaften, 39, 451.

(1953). Klin. Wschr., 31, 85.

Rutter, L. (1950). Nature, Lond., 166, 273.

Scheiffarth, F., and Berg, G. (1952). Z. ges. exp. Med. 119, 550

Schild, K. T., and Maurer, W. (1951). Naturwissenschaften, 38, 303. _- (1952). Biochem. Z., 323, 235.

Schneider, G. (1951). Acta chem. scand., 5, 1020.

- and Wallenius, G. (1951). Scand. J. clin. Lab. Invest., 3, 145. Schweitzer, C. H., and Wittern, A. (1952). Arzneimittel-Forsch., 2, 185. Semm, K., and Fried, R. (1952). Naturwissenschaften, 39, 326.

Slater, R. J., and Kunkel, H. G. (1953). J. Lab. clin. Med., 41, 619.

Smellie, R. M. S., and Davidson, J. N. (1951). Biochem. J., 49, xv.

Smith, E. B., and Dangerfield, W. G. (1954). Personal communication.

Smith, E. W., and Conley, C. L. (1953). Bull. Johns Hopk. Hosp., 93,94 .

Spaet, T. H. (1953). J. Lab. clin. Med., 41, 161.

Squire, J. R. (1953). Brit. med. J., 2, 1389.
Stern, K. G., and Reiner, M. (1946). Yale J. Biol. Med., 19, 67.

Sternberg, J. (1953). Canad. med. Ass. J., 68, 284.

Strange, R. E., and Harkness, N. (1953). Nature, Lond., 171, 77.

Suzuki, T., and Maekawa, Y.(1951). J. pharm. Soc. Japan, 71, 1298.

Svensson, H. (1946). Ark. Kemi. Min. Geol., 22A, No. 10. (1950). Acta chem. scand., 4, 1329.

- and Brattsten, I. (1950). Ark. Kemi., 1, 401.

Swahn, B. (1952). Scand. J. clin. Lab. Invest., $4,98$.

Thing, E., Birch-Andersen, A., and Ravn, H. (1953). Acta endocr., Kbh., 14, 113.

Tiselius, A. (1930). Nova Acta Soc. Sci. upsal., series IV, vol. 7, no. 4.

- (1937). Trans. Faraday Soc., 33, 524.

(1938). Kolloidzschr., 85, 129.

(1953). Disc. Faraday Soc., No. 13, p. 29.

Töpler, A. (1867). Ann. Phys., Lpz., 131, 33, 180.

Turba, F., and Enenkel, H. J. (1950). Naturwissenschaften, 37, 93.

(1951). Ibid., 38, 189.

Van Os, G. A. J. (1952). Biochim. biophys. Acta, 9, 111

- (1953). Chem. Weekbl., 49, 242.

Vignato, L. (1952). Minerva med., Torino (parte sci.), 43 (2), 43.

Vishnyakov, A. O., Dobrovol'skii, D. S., Ermakov, N. V., and Tuckachinskii, S. E. (1952), C.R. Acad. Sci., U.R.S.S., 87, 1053

Wallenfels, K., and Pechmann, E. von (1951). Angew. Chem., 63, 44

Wallenius, G. (1952a). Scand. J. clin. Lab. Invest., 4, 24.

Weber, (1952b). Acta Soc. Med. upsal., 57, 138.

Weicker, H. (1953). Helv. Chim. Wschr., 31, 34, 161.

Wieland, T. (1948). Angew. Chem. A, 60, 313.

- and Bauer, L. (1951). Ibid., 63, 511.

and Fischer, E. (1948). Naturwissenschaften, 35, 29.

and Wischer, E. (1948). Naturwissenschaften,

Wunderly, C. (1953). Chimia, 7, 145.

and Pezold, F. A. (1952). Naturwissenschaften, 39, 493. 